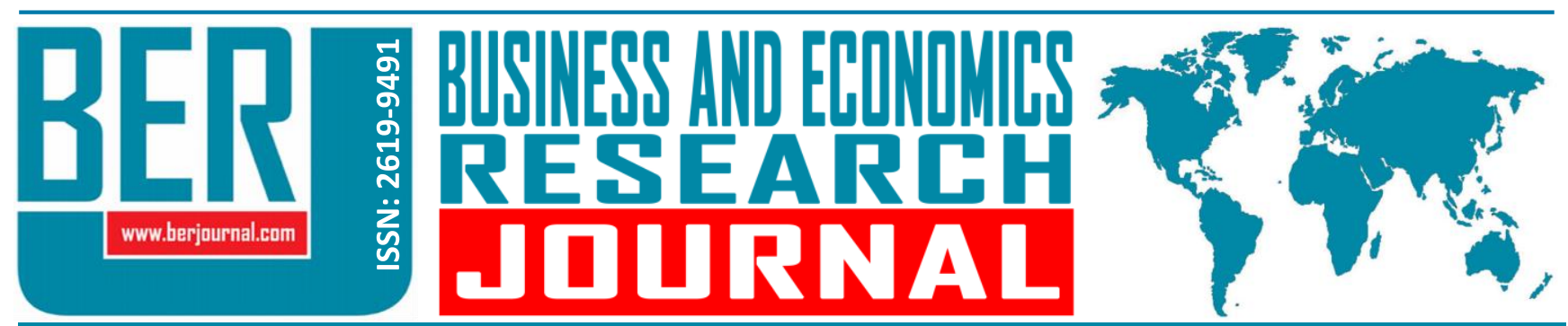

Business and Economics Research Journal Vol. 9, No. 3, 2018, pp. 631-650 doi: 10.20409/berj.2018.128

\section{Deniz Ulaştırma İşletmelerinde Entelektüel Sermaye ve Örgüt Performansı Arasındaki İlişkide Yenilikçiliğin Rolü*}

\begin{abstract}
Murat Yorulmaz ${ }^{\mathrm{a}}$, Guler Alkan ${ }^{\mathrm{b}}$
Öz: Bu çalışmanın temel amacı, küresel ve dinamik rekabet ortamında faaliyette bulunan deniz ulaştırma işletmelerinde entelektüel sermaye, örgüt performansı ve yenilikçilik arasındaki nedensel ilişkilerin belirlenmesidir. Ayrıca bu ilişkide yenilikçiliğin ara değişken rolünün olup olmadığının ortaya çıkartılması da çalışmanın bir diğer amacıdır. Çalışmanın amacına yönelik olarak Türkiye'de faaliyet gösteren, istanbul, Marmara, Ege, Akdeniz ve Karadeniz Bölgeleri Deniz Ticaret Odası (IMEAK) ile Mersin Deniz Ticaret Odası (MDTO)'na kayıtlı 262 deniz ulaştırma işletmesinde görev yapan 413 yöneticiden anket yöntemi ile veriler toplanmıştır. Elde edilen veriler kullanılarak SPSS 21 ve AMOS 21 istatistiksel paket programları yardımıyla araştırma hipotezleri test edilmiştir. Yapılan analizler sonucunda, insan, yapısal ve ilişkisel sermaye bileşenlerinden oluşan entelektüel sermayenin, örgüt performansı ve yenilikçilik üzerinde pozitif ve anlamlı bir etkisinin olduğu ayrıca yenilikçiliğin bu ilişkide kısmı bir ara değişken etkisine sahip olduğu belirlenmiştir.
\end{abstract}

\section{The Role of the Innovation in the Relationship between Intellectual Capital and Organizational Performance in the Maritime Firms}

\begin{abstract}
The main objective of this study is to determine the causal relationships between intellectual capital, organizational performance and innovation in maritime transport firms operating in a global and dynamic competitive environment. It is also another purpose of the study to find out whether there is a mediating variable role in this related innovation. For the purpose of the study, data were collected by survey from 413 executives working in 262 maritime transport operations registered in Istanbul and Marmara, Aegean, Mediterranean and Black Sea Regions Maritime Chamber of Commerce (IMEAK) and Mersin Chamber of Shipping (MDTO). Using the obtained data, research hypotheses were tested with the aid of statistical package programs SPSS 21 and AMOS 21. As a result of the analysis, it was found that the intellectual capital consisting of human, structural and relational capital components has a positive and significant effect on organizational performance and innovation, also innovation has a partial mediating variable effect on this.
\end{abstract}

\section{Anahtar Sözcükler:} Entelektüel Sermaye, Yenilikçilik, Deniz İşletmeciliği, Deniz Ulaştırması

JEL: M10, M12

$\begin{array}{ll}\text { Geliş } & : 02 \text { Nisan } 2018 \\ \text { Düzeltme } & : \text { 14 Mayıs } 2018 \\ \text { Kabul } & : \text { 06 Haziran } 2018 \\ & \\ \text { Tür } & : \text { Araştırma }\end{array}$

Keywords: Intellectual Capital, Innovation, Marine Management, Maritime Transport

JEL: M10, M12
Received : 02 April 2018

Revised : 14 May 2018

Accepted : 06 June 2018

Cite this article as: Yorulmaz M., \& Alkan, G. (2018). Deniz ulaştırma işletmelerinde entelektüel sermaye ve örgüt performansı arasındaki ilişkide yenilikçiliğin rolü. Business and Economics Research Journal, 9(3), 631-650.

The current issue and archive of this Journal is available at: www.berjournal.com

a Asst. Prof., PhD., Yalova University, Yalova Vocational School, Maritime Transportation and Management Program, Yalova, Turkiye, muratyor@gmail.com (ORCID ID: 0000-0002-5736-9146)

b Prof., PhD., Iskenderun Technical University, Shipbuilding and Maritime Faculty, Maritime Transportation Management, Hatay, Turkiye, guler.alkan@iste.edu.tr (ORCID ID: 0000-0002-5736-xxxx)

* Bu çalışma, Prof. Dr. Güler ALKAN'ın danışmanlığında yürütülen ve 2017 yılında tamamlanan “Deniz Ulaştırma Işletmelerinde Entelektüel Sermaye ve Örgüt Performansı Arasındaki ilişkide Yenilikçiliğin Rolü" başlıklı doktora tezinden üretilmiştir. 


\section{Giriş}

Bugünün ekonomik ilişkilerinde, işletmelerin rekabet avantajı yaratmadaki en önemli kaynağı haline gelen entelektüel sermaye ilk defa 1969 yılında John Kenneth Galbraith tarafından, bir işletmenin defter değeri ile piyasa değeri arasındaki farkı açıklamak için kullanılmıştır (Wu ve Chou, 2007). Işletmelerin defter değeri ile piyasa değeri arasındaki fark şerefiye kavramıyla açıklanmaya çalışılmış ancak şerefiye, ticari markalar, patentler ve telif hakları gibi unsurların aradaki bu farkı izah etmeye yeterli olmadığı anlaşılmıştır (Ercan, Öztürk ve Demirgüneş, 2003). İşletme çalışanlarının sahip olduğu bilgi, beceri ve etkinlikleri ile paydaşlarıyla kurdukları ilişkiler, örgütsel fonksiyonlarından kaynaklanan maddi olmayan varlıkların tümü (Williams, 2001) olarak kavramsallaştırılan entelektüel sermayenin içerisinde bilgi, entelektüel mülkiyet ve görünmeyen kaynaklar gibi değerler yer almaktadır.

Entelektüel sermaye tüm işletmelerde işletmelerin büyüklüğüne, sektörlerine göre değişmekle birlikte var olan, işletmeleri başarıya ulaştıracak soyut varlıklar ve kaynaklar olarak ifade edilmektedir (Bölükbaşı, 2014). Soyut varlıklar; patentler, telif hakları, ticari markalar, tasarım hakları, ticari sırlar iken soyut kaynaklar ise çalışanlar, ilişkiler, örgüt kültürü, yönetim anlayışı ve süreçleri gibi gözle görülmeyen bileşenlerden oluşur. Entelektüel sermaye ayrıca paydaşlarla olan ilişkileri, yenilik ve yaratıcılık çabalarını, çalışanların becerilerini ve örgüt yapısını da kapsamaktadır. Sonuç olarak entelektüel sermaye, bir işletmenin belirlediği amaçlarına ulaşmasında değer yaratan ve rekabet avantajı kazandıran görünmeyen varlıkların, bilgisinin ve yeteneklerinin tamamının toplam stokudur (Chen, 2008).

Çalışanların görevlerini yerine getirirken kullandıkları bilgi, beceri ve yeteneklerini, işletmenin faaliyetlerini sürdürebilmesi için sahip olması gereken bilgi sistemleri ve entelektüel varlıklarını ve paydaşlarıyla kurdukları ilişkileri içermesi nedeniyle entelektüel sermaye, müşteriye değer, işletmeye de rekabet avantajı ve yenilikçilik kazandıran önemli bir kaynaktır. Bu açıdan bakıldığında entelektüel sermaye, örgüt performansını ve işletme yenilikçiliğini etkileyen kaynakların başında gelmektedir. Günümüz işletmeleri için hem rekabette üstünlük sağlayan hem de bunu sürdürülebilir hale getiren entelektüel sermaye kavramının incelenmesi zorunlu hale gelmiştir (Baş, Yangil ve Aygün, 2014).

Uluslararası ticarette taşınan yüklerin, hacim bazında \%90'nın, değer bazında ise \%70'nin deniz ulaştırması ile yapılmaktadır (Tuna ve Arabelen, 2013). Deniz ulaştırması diğer ulaştırma türlerine göre daha düşük maliyetli ve büyük miktarlardaki yükleri tek bir seferde taşıyabilme özelliğine sahip olduğu için de en fazla talep edilen ulaştırma türüdür. Dolayısıyla deniz ulaştırma faaliyetleri, uluslararası ticaretin gerçekleşmesinde önemli bir yere sahiptir. "Deniz ulaştırma işletmeleri, okyanusta, denizde veya iç sularda, ticaret gemileriyle yük taşınmasına ilişkin ulusal veya uluslararası faaliyetlerin planlanması, uygulanması ve yönetilmesi işlerini gerçekleştirirler" (Yorulmaz, 2017). Türkiye'de ulusal ve/veya uluslararası deniz ulaştırma faaliyetlerini yürüten deniz ulaştırma işletmelerinde, denizcilik filosuna yeni katılan gemiler sayesinde gerek Türk filosu gerekse dünya filosu büyümektedir. 2017 yıl sonu itibariyle Milli Gemi Sicili ve Türk Uluslararası Gemi Sicili toplamında 150 GT üstü 1999 adet gemi bulunmaktadır. Ayrıca UNCTAD 2017 yılı raporuna göre Dünya sıralamasında Türk bayraklı gemi filomuz 15. Sırada bulunmaktadır (Deniz Ticareti, 2017). Ülke ekonomilerinde önemli yere sahip olan deniz ulaştırma işletmelerinin uluslararası rekabette başarılı olabilmelerinin temelinde, yenilikçi yaklaşımlara ve teknolojilere uyum sağlayabilmeleri yatmaktadır.

Yenilikçilik, mal ve hizmet üretiminde yeni yöntemlerin uygulamaya sokulması ve iş yapış şekillerinde yeni olan uygulamaların geliştirilmesi (Samuel, 2000) ve bunları ticari değer yaratacak şekilde işletme faaliyetlerinde kullanma süreci (Foxall, 1988) aynı zamanda işletmelerin benimsediği ve yenilik olarak uygulanan politika, program, sistem, teslimat, mal ve hizmet için geçerli olan bir yaklaşım veya fikir olarak kabul edilmektedir (Bowen, Rostami ve Piers, 2009). En genel anlamılla yenilikçilik, bilginin ticari ve toplumsal fayda yaratacak şekilde değere dönüştürülmesi (Elçi, 2010) ve önemli olan ekonomiye ya da topluma bir yarar getirebilmesidir (Taş, 2017). Dolayısıyla yenilikçi faaliyetlerin başlangıcı işletmelerdeki bilginin iyi yönetilmesine diğer bir ifade ile entelektüel sermayenin iyi anlaşılmasına bağlıdır.

Işletmelerin rekabet ortamında varlıklarını sürdürebilmeleri için böylesine önemli olan entelektüel sermayenin ölçülmesi, örgüt performansı ve yenilikçilik ile arasındaki nedensel ilişkilerinin belirlenmesi, dinamik bir rekabet ortamında faaliyette bulunan deniz ulaştırma işletmeleri için de önemli olmaktadır. 
Bu çerçevede araştırmanın amacı, küresel ve dinamik rekabet ortamında faaliyette bulunan deniz ulaştırma işletmelerinin sahip olduğu maddi olmayan ve rekabette üstünlük sağlayan kaynaklardan entelektüel sermayelerinin, bu işletmelerdeki yöneticilerin bakış açılarına göre ölçülmesi ve entelektüel sermaye, örgüt performansı ve yenilikçilik arasındaki nedensel ilişkilerin belirlenmesidir. Bu ilişkide yenilikçiliğin ara değişken rolünün olup olmadığının ortaya çıkartılması da bu çalışmanın bir diğer amacıdır.

Ulusal ve uluslararası literatür incelendiğinde, birçok sektör açısından İşletmelere değer katan entelektüel sermaye kavramı ve entelektüel sermaye ile örgüt performansı ve yenilikçilik arasındaki ilişkilerin incelendiği (Subramaniam ve Youndt, 2005; Kutukiz ve Tunçbilek, 2008; Santos-Rodrigues, Faria, Cranfield ve Morais, 2013; Karakaş, Öz ve Yıldız, 2017), ancak deniz ulaştırma işletmelerinde entelektüel sermaye ile örgüt performansı ve yenilikçilik arasındaki nedensel ilişkileri belirlemeye yönelik araştırmanın olmadığı göze çarpmaktadır. Dolayısıyla çalışmanın literatürdeki bu boşluğun doldurulmasına katkı sağlayacağı değerlendirilmektedir.

\section{Kavramsal Çerçeve}

\subsection{Entelektüel Sermaye}

Entelektüel sermaye, işletmeye değer kazandırmak için kullanılabilecek her türlü yönetim yetenekleri, patentler, iş süreçleri, tecrübe, müşteri ve tedarikçileri hakkındaki bilgilerin tamamını içeren temel bir varlıktır. Entelektüel sermaye, işletmelerin bünyesinde olan insan kaynağını, işletmelerin organizasyon yapısını, müşterileri ile kurduğu ilişkileri kapsayan, işletmeye rekabet konusunda avantaj sağlayacak sahip olduğu bilgi sistemlerinin, geçmiş tecrübelerinin, paydaşlarıyla ilişkilerinin ve tüm işletmeyi içine alan mesleki becerilerinin yarattığı değerdir (Edvinsson ve Malone, 1997). Bontis, Keow ve Richardson (2000) entelektüel sermayeyi, işletmenin sahip olduğu tüm soyut kaynaklar ve bunların işletmeye kazandırdığı üstünlükler ve ayrıcalıklar olarak ifade etmiştir. Özetle, entelektüel ve sermaye kavramlarının anlamlarından hareketle entelektüel sermaye, bilgi birikimi olarak tanımlanabilir (Altunoğlu ve Demir, 2012). Entelektüel sermaye ile ilgili yapılan çalışmalar incelendiğinde, entelektüel sermayenin tanımlanmasında özellikle işletme çalışanlarına, işletmeyi diğer işletmelerden ayıran değerlerine ve tüm iç-dış çevresiyle kurduğu ilişkilere vurgu yapıldığı görülmektedir. Bu noktadan hareketle, entelektüel sermaye işletmenin sahip olduğu insan kaynağının, yönetim anlayışının ve paydaşlarıyla kurduğu ilişkilerinin etkileşimi ve toplamıdır şeklinde tanımlanabilir.

Entelektüel sermaye kavramını oluşturan bileşenler incelendiğinde ise genellikle entelektüel sermayenin; insan sermayesi, yapısal sermaye ve ilişkisel sermaye/müşteri sermayesi bileşenlerinden oluştuğu yönünde görüş birliği vardır (Koçoğlu, İmamoğlu ve İnce, 2009).

Entelektüel sermaye bileşenlerinin başında gelen insan sermayesi, en basit haliyle, bir işletmede bulunan çalışanların sahip olduğu bireysel bilgi, beceri, tecrübe, motivasyon ve iş yapma tarzı olarak ifade edilebilir (Stewart, 1997). Dolayısıyla insan sermayesi, çalışanın, işletmede çalışmaya devam ettiği sürece işletmenin sahip olduğu entelektüel sermayedir. İşletmelerin bünyesinde var olan, onları rakiplerinden ayıran ve rakiplerince taklit edilemeyen en önemli kaynaklarından biri olan insan sermayesine sürekli yatırım yapmak, çalışanların bilgi birikimini, yaratıcılığını ve problem çözme yeteneğini geliştirecektir.

Yapısal sermaye, işletmenin yönetim anlayışı, değerleri, rutinleri, iş süreçleri ve bilgi sistemlerini kapsayan ve bunlar sayesinde işletmenin varlığını sürdürebilmesine imkân tanıyan yeteneklerdir (Cabrita ve Vaz, 2005). Yapısal sermaye, işletme stratejisi, kültürü, yönetim anlayışı, bilgi sistemleri ve teknolojileri, patentler, telif hakları, ticari markalar ve veri tabanları gibi (Seetharaman, Low ve Saravanan, 2004), işletmeye ait olan ve işletmenin ürün veya hizmetlerine değer katan varlıkların bir bütünüdür (O’Donnell, 2004). Buna göre yapısal sermayenin tamamı işletmeye ait işletmeye özgü değerlerden oluşmaktadır.

ilişkisel sermaye veya müşteri sermayesi ise, işletmenin müşterileri, tedarikçileri, yatırımcıları gibi tüm paydaşları ile ilişkilerini ve paydaşların işletmeye yönelik tutum ve algılarını etkileyen entelektüel sermaye bileşenidir (Beattie ve Thomson, 2007). iliş̧isel sermaye, işletmenin dış çevresindeki paydaşlarıyla (müşteriler, tedarikçiler, resmî kurumlar vb.) olan ilişkilerini ve paydaşların işletmeye bakış açılarını 
kapsamaktadır (Isaac vd., 2010). iliş̧kisel sermaye, işletmenin faaliyetleri sırasında dış ilişkilerinde yarattığı değer (Ramirez, 2010) ve ilişki içerisinde olduğu tüm dış çevresel faktörlerle olan ilişkilerine istinaden geliştirdiği değer olarak tanımlanabilir. Bazı araştırmacıların müşteri sermayesi olarak da adlandırdığı ilişkisel sermaye, müşteri sermayesini de kapsayan ve içine alan, işletme için değer yaratabilecek, dış çevresindeki tüm taraflarla ilgilidir.

İşletmeler küresel rekabet ortamında güçlerini artırmak, piyasada etkin olabilmek ve yeni stratejiler geliştirebilmek için ellerindeki en önemli zenginlik kaynağı olan entelektüel sermayeyi ortaya çıkartmak ve ölçmek durumundadır. Entelektüel sermayenin özelliği gereği maddi olmayan varlıkları kapsaması, işletmelere ve işletmelerin sektörlerine göre farklılıklar göstermesi sebebiyle ölçülmesi kolay değildir. Araştırmanın amacına yönelik olarak bu çalışmada, deniz ulaştırma işletmelerindeki entelektüel sermayeyi ölçmek için literatürde sıklıkla kullanılan Bontis, Keow, ve Richardson (2000) entelektüel sermaye ve örgüt performansı arasındaki ilişkilerin incelendiği algısal ölçüm yönteminden faydalanılmıştır.

\subsection{Yenilikçilik}

Drucker'a göre uzun vadeli olarak örgüt performansı etkileyen inovasyon (Desphande ve Farley, 2003) kavramı köken olarak, yeni anlamına gelen Latince "innovatus" kelimesinden türetilmiş (Kelley ve Littman, 2005) ve Türkçe literatürde inovasyon kavramı "yenilik" "yenilenme" veya "yenilikçilik" olarak kullanılmaktadır (Eraslan vd., 2008). Yenilik tanım olarak Oslo Kılavuzu'nda; "Yeni veya fark edilir derecede iyileştirilmiş bir mal/ hizmet, süreç, yeni bir pazarlama tekniği ya da yeni bir organizasyonel yöntemin işletme içi uygulamalarda, işyeri organizasyonunda veya dış ilişkilerde gerçekleştirilmesi" (Oslo Kılavuzu, 2005) şeklinde ifade edilmektedir. Elçi (2007) yenilikçiliği, ürünlerde, hizmetlerde veya iş yapış süreçlerinde, biçimlerinde ekonomik ve toplumsal bir değer oluşturmak için ortaya çıkartılan farklıık, değişiklik ve yenilik olarak tanımlamıştır. Yenilikçilik kavramı ilk kez Schumpeter tarafından ele alınmış ve ekonomik ilerleyişin ve kalkınmanın sürükleyici, itici gücü olarak ifade edilmiştir (Becheikh, Landry ve Amara, 2006).

Teknolojinin ülkeler arasında hızla yayılmasına olanak sağlayan yenilikçilik (Low, 2009) kavramı aynı zamanda işletmeler için rekabet ortamında en belirleyici unsur olması (Pabuşcu ve İmamoğlu, 2017) nedeniyle verimlilik, kalite, hız ve esneklik kavramlarından sonra işletmeler açısından tarihsel süreç içerisinde, küresel rekabetin merkezine yerleştiği söylenebilir. Çünkü yenilikçilik, işletmelere rekabette avantaj yaratan ve karlııklarının artmasını sağlayan önemli bir güçtür. Özetle yenilikçilik, işletmelerin rekabetçi ortamda uzun dönemli olarak varlıklarını devam ettirebilmeleri için bulundukları sektörün dinamiklerini, piyasa koşullarını ve müşterilerinin beklentilerini dikkate alarak yeni ürün, hizmet, iş süreçleri veya yönetim yaklaşımlarını ticari bir değeri olacak şekilde ortaya çıkartmak için yapılan her türlü faaliyeti kapsamaktadır.

Literatürde yenilikçiliğin çeşitlerine ilişkin birçok sınıflandırma vardır. Örneğin, Johne (1999) yenilikçiliği, ürün, süreç ve pazar yenilikçiliği şeklinde, Armbuster vd., (2008) teknik ürün, teknik olmayan hizmet, teknik süreç ve örgütsel (teknik olmayan süreç) yenilikçilik olarak dört grupta sınıflandırmaktadır. Oslo Kılavuzu (2005) yenilikçiliği türlerine göre; ürün/hizmet, süreç, pazarlama ve örgütsel/organizasyonel yenilikçilik, boyutlarına göre ise radikal ve kademeli biçiminde ayırmaktadır. Yenilikçilik temelde tüm organizasyonları kapsayacak şekilde yönetsel yenilikçilik ve teknik yenilikçilik olarak sınıflandırılabilir (Özdevecioğlu ve Biçkes, 2012). Bu çerçevede çalışmada, deniz ulaştırma işletmelerinde yürütülen yönetsel ve teknik yenilikçilik faaliyetler, yenilikçilik faaliyetleri olarak ele alınmış ve bu kapsamında değerlendirilmiştir.

Yönetsel yenilikçilik, bir işletmenin tüm yönetimsel ve yapısal süreçleriyle ilgili yapılan yenilikleri kapsamaktadır. Teknik yenilikçilik ise işletmenin sunduğu hizmet veya ürün süreçlerinde ya da bunlarla ilgili teknolojide gerçekleştirilen yeniliklerdir (Damanpour ve Evan, 1984). Yönetsel yenilikçilik, işletme çalışanlarının birbirleriyle ve paydaşlarıyla olan etkileşimlerini, ilişkilerini belirleyen şekillendiren tüm yapı ve sistemle ilgilidir (Damanpour vd., 2009). Yönetsel yenilikçilik, işletmenin organizasyon yapısında hem iç hem de dış ilişkilerinde veya ticari uygulamalarında yeni ve farklı yöntemleri uygulayabilmesidir. Örgütsel performansı artırabilmek için de yönetsel ve teknik yenilikçiliğin işletme içinde uyumlu biçimde gerçekleştirilebilmesi gereklidir. 
Günümüzde işletmeler için sürdürebilir rekabet avantajı kazandıran yenilikçi yaklaşımlar (Mol ve Birkinshaw, 2009) küresel rekabet ortamında faaliyetlerini sürdürmek zorunda olan deniz ulaştırma işletmeleri için de önemli bir unsurdur. Yenilikçilik, başka işletmelerden transfer yoluyla da yapılabilmekte, dolayısıyla yenilikçiliğin sadece işletme bünyesinde yapılması gerekmemektedir. Lojistik hizmet işletmelerine bakıldığında, yenilikçiliğin teknoloji temelli olduğu görülmektedir (Chapman, Soosay ve Kandampally, 2002). Lojistik hizmet sağlayıcı işletmeler grubunda yer alan deniz ulaştırma işletmelerinde de yenilikçi yaklaşımların çoklukla yeni teknolojileri takip etme, yeni teknolojileri kullanma, yeni teknolojiye uyum sağlama ve operasyonel süreçlerine uygulama becerisi şeklinde gerçekleştiği söylenebilir.

Teknolojinin hızla gelişmesiyle birlikte deniz ulaştırma sektöründe de önemli yenilikler yapılmaktadır. Özellikle gemi inşa sektöründeki teknolojik gelişmeler sayesinde yeni ve modern ticaret gemilerinin yapılması deniz ulaştırmasını hızlandırmış ve ayrıca buzlu bölgelerde seyir yapabilen gemilerin yapılmasıyla birlikte deniz taşımacılı̆ının yaygınlaşması ve daha güvenli olması sağlanmıştır. Bunların dışında katlamalı konteynerlerin kullanılması, e-navigasyon sistemi, modern ve teknolojik seyir yardımcıları (ECDIS, AIS) ve bilgi sistemleri ile donatılan gemileri işleten deniz ulaştırma işletmelerinin, teknolojik yeniliklere uyum sağlama şeklinde yenilikçi yaklaşımları benimsediği görülmektedir. Ayrıca kalite yönetim sisteminin denizcilikteki bir uygulaması olan emniyetli gemi yönetim sisteminin (ISM) gemilerde ve ofiste uygulanması, firmada uzun süreli çalışmayı özendirici olan ödüllerin ve hizmet içi eğitimlerin deniz ulaştırma işletmelerince verilmesi ve bunların uygulanması yönetsel yenilikçiliğe verilebilecek örneklerdir.

\subsection{Entelektüel Sermaye, Yenilikçilik ve Örgüt Performansı Arasındaki İlişkiler}

Bilginin örgüte değer yaratacak şekilde dönüştürülmesi olarak tanımlanan entelektüel sermaye (Önce, 1999), işletmenin yenilikçilik ve yaratıcılık faaliyetlerinin kaynağı (Chen, 2008) ve işletmenin yenilikçilik gücünü artıran önemli bir unsurdur (Toraman vd., 2009). İşletmenin örgüt performansının artması da ancak yenilikçilik çabalarının artmasıyla mümkün olabilir (Ruiz-Arroyo vd., 2012). Bu nedenle yenilikçiliğin hem entelektüel sermaye hem de örgüt performansı ile ilişkisini inceleyen pek çok çalışma bulunmaktadır. Bunların bir kısmı aşağıda verilmiştir.

Damanpour, Szabat ve Evan (1989), yenilikçilik çeşitleri ve örgüt performansı arasındaki ilişkiyi inceledikleri çalışmalarında elde ettikleri verileri doğrulayıcı faktör analizi ile değerlendirmişlerdir. Araştırma bulgularına göre, örgüt yapısı ile uyumlu olan teknik yenilikçiliğin örgüt performansı üzerinde önemli derecede bir etkisi olduğu ortaya çıkmıştır.

Jin, Hewitt-Dundas ve Thompson (2004) Kuzey İlanda ve Irlanda Cumhuriyeti'nde faaliyette bulunan 531 üretim işletmesi örnekleminde yaptıkları araştırmada, yenilikçi olmayanlar, yaratıcı olanlar, adapte olanlar ve çok yönlü yenilikçi olanlar şeklinde dört grupta topladıkları işletmelerinden, yenilikçi olan işletmelerin örgüt performanslarının yenilikçi olmayan işletmelere göre daha yüksek olduğu sonucuna ulaşmışlardır. Ayrıca çok yönlü yenilikçi özelliklere sahip işletmelerin örgütsel performanslarının, yaratıcı olan ve adapte olan işletmelerin örgütsel performanslarına göre daha yüksek olduğunu tespit etmişlerdir.

Subramaniam ve Youndt (2005) çalışmalarında, entelektüel sermayenin işletmelerde yenilikçiliği nasıl etkilediğini incelemişlerdir. 93 işletmeden boylamsal çalışma ile elde etikleri verilere göre, entelektüel sermaye bileşenlerinden insan, yapısal ve sosyal sermayenin birbirleriyle ilişkili olduğunu ve artan ile radikal yenilikçiliği olumlu yönde etkilediğini ortaya çıkarmışlardır.

Zehir ve Özşahin (2006), Türkiye'de imalat sektöründe faaliyet gösteren ve ilk 500 işletme içerisinde yer alan 73 işletme üzerinde yaptıkları araştırmada, stratejik karar verme hızını etkileyen örgütsel, çevresel faktörlerin örgüt performansı ile ilişkisini incelemişlerdir. Anket yöntemiyle 214 orta ve üst düzey yöneticiden elde edilen verilerin regresyon analizlerine göre, örgütsel faktörler arasına yer alan yenilikçiliğin, örgüt performansını pozitif ve anlamlı olarak etkilediği ortaya çıkmıştır.

Kutukiz ve Tunçbilek (2008), turizm sektöründe faaliyet gösteren 26 işletme üzerinde yaptıkları araştırmada, yenilikçilik, rekabetçilik ve yeni teknoloji kullanımının işletme performansı üzerindeki etkisini araştırmışlardır. İşletme yöneticilerinden anket tekniği ile elde ettikleri verilerle yapılan regresyon analizlerin 
bulgularına göre, sırasıyla en fazla yeni teknoloji kullanımının, yenilikçiliğin ve rekabetçiliğin işletme performansı üzerinde pozitif ve anlamlı etkisinin olduğunu ortaya çıkmıştır.

Damanpour, Walker ve Avellaneda (2009) yaptıkları çalışmada, İngiltere bulunan 428 kamu hizmet kurumunun dört yıl süreyle yenilikçilik faaliyetlerini incelemişlerdir. Bu çalışmada hizmet, teknolojik ve yönetsel süreç boyutlarından oluşan yenilikçiliğin, örgüt performansı üzerindeki etkisinin zaman içerisinde bu yenilikçilik boyutlarının karşııkı etkileşimine bağlı olduğu öne sürülmektedir.

Eren, Yücel ve Eren (2010), örgüt performansını etkileyen, pazar odaklılık ve çevresel belirsizliğin, müşteri odaklıık ve yenilikçilik ile ilişkisini incelikleri çalışmada, sadece yenilikçiliğin örgüt performansını etkilediğini belirtmişlerdir ve bu araştırmada Kocaeli ilinde bulunan ve otomotiv sektöründeki 119 işletmenin 198 yöneticisinden anket tekniği ile elde edilen veriler yapısal eşitlik modellemesi ile analiz edilmiştir.

Eren ve Kaplan (2014), Kocaeli ilinde özel sektörde faaliyette bulunan üretim işletmelerindeki 609 yönetici üzerinde kurumsal yetkinlik olarak belirledikleri yenilik yetkinliğinin, örgüt performansı üzerindeki etkisini incelemişlerdir. Anket yöntemi ve regresyon analizi kullanılarak yapılan araştırma bulgularına göre, yenilik yetkinliğinin nitel ve nicel performans göstergelerinden oluşan örgüt performansı üzerinde pozitif ve anlamlı bir etkisinin olduğunu tespit etmişlerdir.

Cezlan (2014) İstanbul ilinde faaliyette bulunan kamu ve özel hastaneler üzerinde yaptığı çalışmasında entelektüel sermayenin firma yenilikçiliği ve örgüt performansına olan etkisi incelemiştir. İstanbul'daki kamu hastanelerinden 133, özel hastanelerden 122 olmak üzere toplam 245 orta ve üst düzey yöneticinin katıldığı anket çalışmasında, entelektüel sermayenin bileşenlerinden insan ve ilişkisel sermayenin firma yenilikçiliği üzerinde pozitif bir etkisi varken, organizasyonel sermayenin bir etkisinin olmadığı tespit edilmiştir. Ayrıca entelektüel sermaye bileşenlerinden insan sermayesi ile örgüt performansı arasında yenilikçiliğin tam ara değişken etkisinin olduğu araştırma bulgularına göre rapor edilmiştir.

Aramburu vd. (2015) Colombiya'da faaliyet gösteren 69 teknoloji temelli işletme üzerinde yaptıkları çalışmada, işletmelerin sahip olduğu yenilikçilik yeteneğinin rekabette üstünlük sağlaması için bilgi yönetiminin ve entelektüel sermayenin işletme yönetimi açısından önemli olduğunu vurgulamışlardır. Bu çalışmada entelektüel sermaye açısından işletme yenilikçiliğinin ve performansının önemini ortaya koymak ve yapısal sermayenin yenilikçilik üzerindeki etkisinin değişik işletme koşullarındaki etkisini incelemişleridir. Araştırmada entelektüel sermayenin yenilikçilik yeteneği üzerinde anahtar bir rol oynadığı ve özellikle yapısal sermayenin işletme yenilikçiliği üzerinde etkili bir unsur olduğu ve bu nedenle yenilikçilik yeteneğini artırmak isteyen işletmelerin entelektüel sermayelerine yatırım yapmaları gerektiğini ifade edilmiştir.

Karakaş, Öz ve Yıldız (2017), İstanbul ilinde faaliyette bulunan beş yıldızlı otel işletmelerinde yaptıkları araştırmada yenilikçilik ve örgüt performansı arasındaki ilişkiyi incelemişlerdir. 48 yöneticinin katıldığı anket çalışmasının verileri doğrulayıcı faktör analizi ve regresyon analizi ile analiz edilmiş ve yenilikçiliğin örgüt performansı üzerindeki etkisinin \%48 oranında olduğu rapor edilmiştir. Sonuç olarak, yoğun rekabet şartlarında işletmelerin sürekliliğini sağlayabilmeleri adına piyasaya ayak uydurmak için yenilikçi faaliyetleri vurgulamanın önemli olduğu ve işletmelerin elde ettiği verilere göre, işletmelerin yenilik faaliyetlerinin örgüt performansı etkilediği ifade edilmiştir.

Entelektüel sermaye ve örgüt performansı arasındaki ilişki ile ilgili literatür incelendiğinde, sektörlere göre düzeysel farklılıklar olsa da entelektüel sermaye, yenilikçilik ve örgüt performansı arasında bir ilişki ve etkileşim söz konusudur. Buna göre Şekil 1'deki araştırma modeli geliştirilmiştir. Şekil 1'de entelektüel sermayeyi oluşturan bileşenleri, örgüt performansı ve yenilikçilik arasındaki ilişkiyi sembolize eden araştırma modelinde, entelektüel sermaye ve örgüt performansı arasındaki doğrudan ilişki ve bu ilişkide yenilikçiliğin ara değişken etkisinin olup olmadığı araştırılmaktadır.

Yukarıdaki literatür esas alınarak Şekil 1'de ortaya konan araştırma modeli oluşturulmuştur. Bu modele dayalı olarak oluşturulan araştırma hipotezleri ise aşağıda belirtilmiştir.

Hipotez 1: Deniz ulaştırma işletmelerinde entelektüel sermaye, örgüt performansını pozitif ve anlamlı yönde etkiler. 
Hipotez 2: Deniz ulaştırma işletmelerinde entelektüel sermaye, yenilikçiliği pozitif ve anlamlı yönde etkiler

Hipotez 3: Deniz ulaştırma işletmelerinde yenilikçilik, örgüt performansını pozitif ve anlamlı yönde etkiler.

Hipotez 4: Deniz ulaştırma işletmelerinde entelektüel sermaye ve örgüt performansı arasındaki ilişkide, yenilikçiliğin ara değiş̧en etkisi vardır.

Şekil 1. Araştırma Modeli.

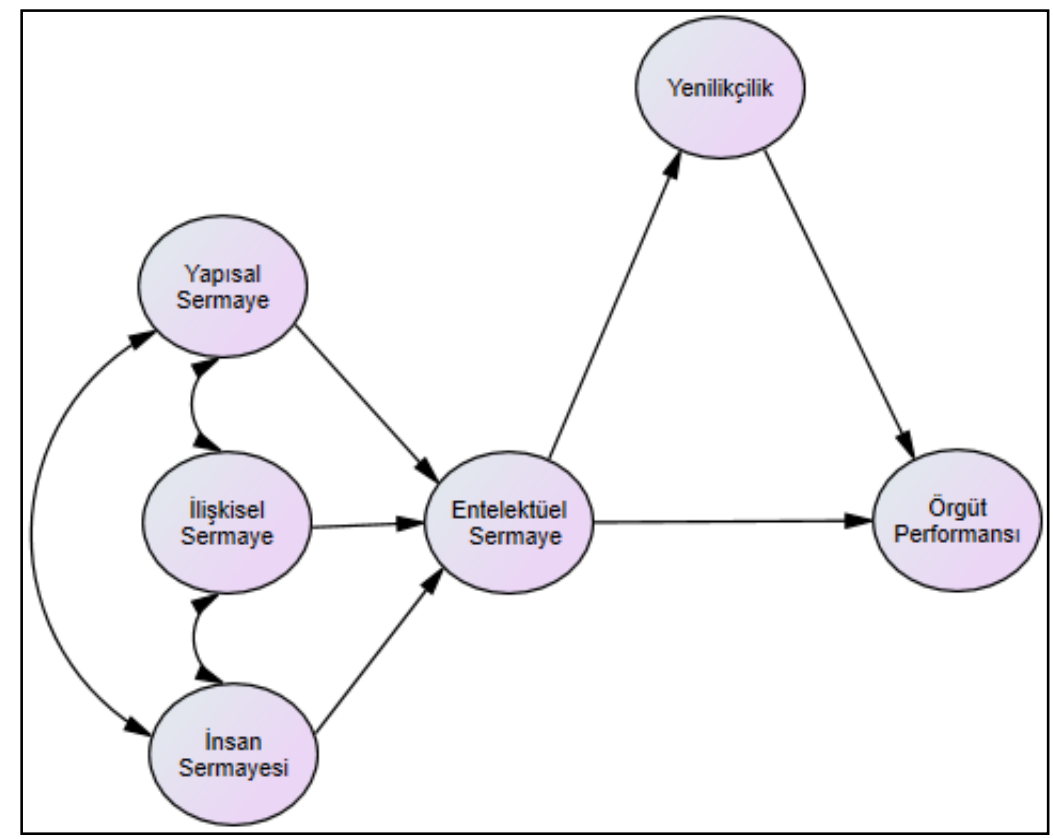

\section{Malzeme ve Yöntem}

\subsection{Araştırma Yöntemi}

Araştırma anket yöntemi kullanılarak yapılmıştır. Anket yöntemiyle elde edilen sayısal verilerin, yapısal geçerliliğini test etmek için Açıklayıcı ve Doğrulayıcı faktör analizi, güvenilirliğini test etmek için de güvenilirlik analizinde Cronbach Alfa katsayısı kullanılmıştır. Tüm ölçeklerin geçerliliğini ve güvenirliğini belirlendikten sonra elde edilen değişkenler arasındaki ilişkileri incelemek ve önerilen hipotezleri test etmek için; Korelasyon analizi, Yapısal Eşitlik Modellemesi ile Yol analizi, Ara değişken analizi ve SOBEL testi, SPSS 21 ve AMOS 21 istatiksel paket programları kullanılarak yapılmıştır.

\subsection{Veri Toplama Yöntemi ve Ölçüm Araçları}

Araştırmada veri toplama yöntemi olarak belirlenen anketlerin seçilmesinde, araştırma konularını kapsayan ve daha önceki çalışmalarda geçerliliği, içsel tutarlığı ve güvenilirliği kanıtlanmış ölçekler tercih edilmiştir. Ek 1'de sunulan anket formu üç bölümden oluşmaktadır. Birinci bölümde, ankete katılan yöneticilerin; cinsiyet, yaş, eğitim durumu gibi demografik özelliklerine yönelik sorular, ikinci bölümde araştırmaya katılan işletmelerin faaliyet alanları ve faaliyet süresini belirlemeye yönelik sorular, üçüncü bölümde ise entelektüel sermaye, yenilikçilik ve örgüt performansı ölçekleri bulunmaktadır. Ölçüm araçlarındaki sorular, 5'li Likert ölçeği esas alınarak ve önermeler; "1=Kesinlikle katılmıyorum; 2=Katılmıyorum; 3=Kararsızım; 4=Katılıyorum; 5=Kesinlikle katılıyorum" şeklinde hazırlanmıştır. 


\subsubsection{Entelektüel Sermaye Ölçeği}

Entelektüel sermaye ölçeği, insan sermayesi, yapısal sermaye ve ilişkisel sermaye boyutlarını ölçmek üzere toplam 29 sorudan oluşmaktadır. Entelektüel sermaye ölçeğinde, ilk kez Bontis vd. (2000) Malezya'da kullandığı ve Erkuş'un (2007) söz konusu çalışmadan faydalanarak Türkiye'de savunma sanayine uyguladığı ve geliştirdiği değişkenler derlenerek on bir sorudan oluşan insan sermayesi ve dokuz sorudan oluşan yapısal sermaye ölçeği bulunmaktadır. Entelektüel sermayenin diğer boyutu olan ilişkisel sermaye ölçeği için de Bozbura ve Toraman'ın (2004) Türkiye'de entelektüel sermayenin ölçülmesi ile ilgili geliştirdiği modelinde inşaat sektörüne uyguladığı dokuz soru kullanılmıştır.

\subsubsection{Yenilikçilik Ölçeği}

Yenilikçilik ölçeği, işletme yenilikçilik düzeyini ölçek üzere olarak beş maddeden oluşmaktadır. Yenilikçilik ölçeğinde bulunan önermeler, Peçen ve Kaya (2013) ABD firmalarında insan kaynakları yönetimi uygulamaları, organizasyonel iklim ve organizasyonel yenilikçilik düzeyini araştırdıkları çalışmalarında kullandıkları, Yang (2012) deniz lojistik firmalarının, lojistik kapasitesi ve örgüt performansı arasındaki ilişkide yenilikçiliğin moderatör etkisini araştırdığı çalışmasında kullandığı ve Daugherty vd. (2011) değişik örgüt yapılarının lojistik hizmetlerde yenilikçilik yeteneğine ve örgüt performansına etkisini inceledikleri çalışmalarında kullandıkları sorulardan faydalanılarak hazırlanmıştır.

\subsection{3. Örgüt Performansı Ölçeği}

Örgüt performansı ölçeği Yang (2012) deniz lojistik firmalarının, lojistik kapasitesi ve örgüt performansı arasındaki ilişkide yenilikçiliğin moderatör etkisini araştırdığı çalışmasında kullandığı, finansal ve nitel performans göstergeleri olan altı sorudan oluşmaktadır.

\subsection{Araştırma Örnekleminin Belirlenmesi}

Araştırmanın amacına yönelik olarak araştırma evrenini, Türkiye'de faaliyet gösteren denizcilik işletmelerinden; gemi işletmeciliği yapan İstanbul ve Marmara, Ege, Akdeniz ve Karadeniz Bölgeleri Deniz Ticaret Odası (IMEAK) ile Mersin Deniz Ticaret Odası (MDTO)'na kayıtı deniz ulaştırma işletmelerinde görev yapan yöneticiler oluşturmaktadır. Yöneticiler kavramı, deniz ulaştırma işletmelerindeki genel müdürleri, genel müdür yardımcılarını, departman müdürlerini, müdür yardımcılarını ve enspektörleri kapsamaktadır. IMEAK ve MDTO' ya kayıtlı deniz ulaştırma işletmelerinin insan kaynakları departmanında görev yapan çalışanlarıyla yüz yüze, telefon veya e-mail ortamından ulaşılarak araştırma hakkında bilgi verilmiş ve araştırmaya katkı sağlamaları açısından anket formunun, işletmelerindeki tüm yöneticiler tarafından doldurulması talep edilmiştir. Bu şekilde yapılan görüşmeler sonucunda 262 deniz ulaştırma işletmesinden toplam 432 anketin geri dönüşü sağlanmıştır. Geri dönüşü olan 432 ankettin, 19 tanesi eksik bilgi içerdiği veya birden fazla seçenek işaretlendiği için iptal edilmiştir. Sonuçta toplam 413 anket araştırma hipotezlerini test etmek için değerlendirmeye alınmıştır.

Araştırmada \%95 güven aralığında ve \%5 örneklem hatasına karşılık gelen evren büyüklüğü ve bu evren büyüklüğünü temsil edebilecek örneklem sayısı açısından 413 kişilik bir örneklem, 1.000.000'den fazla kişilik bir evereni temsil edebilmektedir (Yazıcıoğlu ve Erdoğan, 2004). Ayrıca çok değişkenli istatistiksel analizlerde, ölçüm araçlarındaki soru sayısının 5 veya 10 katı kadar örneklem sayısının yeterli olacağını belirten Kline (1994) ve Bryman ve Cramer (2001) gibi araştırmacılardan hareketle toplam 40 soruluk bir ölçek için 413 kişilik bir örneklem büyüklüğünün yeterli olduğu anlaşılmaktadır.

\section{Bulgular}

\subsection{Tanımlayıcı İstatistikler}

Araştırmaya katılan firma yöneticilerinin çoğunluğu \%55,7'si (230 kişi) kuru yük piyasasında, \%5,1'i (21 kişi) karma gemi işletmeciliği yapan firmalarda görev yapmaktadır. Bu yöneticilerin \%29,1'i (120 kişi) 21 yıl ve daha fazla süre faaliyette bulunan firmalarda görev yaparken, \%11,1'i (46 kişi) 1 ile 5 yıl arası faaliyette 
bulunan firmalarda görev yapmaktadır. Aynı zamanda yöneticilerin \%33,4'ü (138 kişi) 31 ile 90 arası çalışanın olduğu firmada yöneticilik yaparken, \%9,4'ü (39 kişi) 30 ve daha aza sayıda çalışanın olduğu firmada yöneticilik yapmaktadır.

Araştırmaya katılan yöneticilerin çoğunluğu \%86,9'u (359 kişi) erkek, \%13,1'i (54 kişi) kadın ve \%41,4'ü (171 kişi) 41 ile 50 yaş aralığında iken \%5,5'i (23 kişi) 25 ve daha küçük yaş aralığındadır. Yöneticilerin öğrenin durumuna bakıldığında ise çoğunluğunun \%41,1'i (170 kişi) lisans düzeyinde bir üniversiteden mezun olduğu, \%9,6'ı (40 kişi) ise yüksek lisans veya doktora düzeyinde eğitim aldığı ayrıca bu yöneticilerden \%69,5’nin (280 kişi) denizcilik ile ilgili bir eğitim aldığı anlaşılmaktadır. Aynı zamanda anketlere cevap veren yöneticilerin $\% 40,5^{\prime} i$ (167 kişi) departman müdürü, $\% 6,6$ sı (27 kişi) ise genel müdür düzeyinde olduğu görülmüştür.

\subsection{Geçerlilik ve Güvenilirlik Analizleri}

Ölçeklerin yapısal geçerliliğini belirlemek için öncelikle Açıklayıcı Faktör Analizi (AFA) sonrasında ise Doğrulayıcı Faktör Analiz (DFA) yapılmıştır.

Verilerin AFA için yeterli olup olmadığı Kaiser-Meyer-Olkin (KMO) ve Barlet küresellik testi ile incelenmiştir. Verilerin faktör analizi yapmak için uygun çıkması üzerine $(0,50<K M O ; p<0,01)$ ölçeğin yapı geçerliliğini ve faktör yapısını incelemek için AFA uygulanmıştır. Temel bileşenler analizi faktörleşme yöntemi olarak ve eksen döndürme yöntemi olarak da Varimax rotasyonu seçilerek, birbirleriyle ilişkili olan değişkenlerin belli bir faktör grubu oluşturabilmeleri sağlanmış ve faktör yükleri 0,5'den, öz değerleri ise 1'den yüksek olacak (Büyüköztürk, 2007) şekildeki değişkenler AFA'ya dahil edilmiştir.

Entelektüel sermaye ölçeğine ilişkin verilerin faktör analizi yapmak için (KMO: 0,806; $p<0,01$ ) yeterli çıkması üzerine AFA ile ilk etapta entelektüel sermaye ölçeğindeki 29 soru faktör analizine alınmıştır. Analiz süresince bu 29 sorudan, ilk aşamada hiçbir faktör altına girmemiş olanlar daha sonra iki farklı faktöre birden yüklenen sorular analiz dışında bırakılıp yeniden faktör analizi yapılmıştır. Bütün analizlerde bu sıra takip edilerek hiçbir faktör altında toplanmamış veya iki farklı faktöre birden yüklenen soru olmayacak şekilde uygulama yapılmıştır. Bu uygulama sonucunda kalan 21 soru için yapılan AFA'dan 3 faktör elde edilmiştir. Bu faktörler toplam varyansın \%70,21'ni açıklamaktadır. Bu faktörler beklenildiği şekilde entelektüel sermayenin bileşenleri olan ve toplam varyansın $\% 24,79$ 'nı açıklayan yapısal sermaye, toplam varyansın \%23,47'sini açıklayan ilişkisel sermaye ve toplam varyansın \%21,95' ini açıklayan insan sermayesinden oluşmaktadır.

Yenilikçilik ölçeğine ilişkin verilerin faktör analizi yapmak için uygun çıkması üzerine (KMO: 0,760; $p<0,01)$ AFA ile yenilikçilik ölçeğindeki beş soru faktör analizine tabi tutulmuştur. Analiz sonunda ölçeğin yapısına uygun olarak tek faktörlü bir yapı ortaya çıkmıştır ve toplam varyansın $\% 57,92$ 'ni açıklamaktadır. Bu faktör, Yenilikçilik olarak isimlendirilmiştir, çünkü bu faktör; işletme yönetiminin yenilikçi düşünceye verdiği önem ve destek, teknolojik yeniliklere bakış açısı ve geliştirilen iş süreçlerinin işletmeye yaptığı katkılar ile ilgili beş değişkeni içermektedir.

Örgüt performansı ölçeğine ilişkin verilerin faktör analizi yapmak için uygun çıkması üzerine (KMO: $0,756 ; p<0,01)$ AFA yöntemi ile yapılan analiz sonucunda örgüt performansı ile ilgili değişkenler tek faktör altında toplanmış ve Örgüt performansı olarak isimlendirilmiştir, çünkü bu faktör; firmanın taşıma maliyetleri, pazar payı, yatırımlarının getirisi ve müşterilerin işletmeye bağılığı ilgili altı değişkeni içermektedir. Bu faktör toplam varyansın $\% 46,15^{\prime}$ ni açıklamaktadır.

Entelektüel sermaye, yenilikçilik ve örgüt performansı ölçeklerinin yapısal geçerliliğini test etmek yapılan AFA'nın sonucunda elde edilen faktörlerin, faktör yüklerinin ve toplam açıklanan varyanslarının yeterli olduğu görülmüştür.

AFA ile elde edilen faktörlere DFA uygulanmıştır. DFA'nın önemli varsayımlarından olan verilerin normal dağılım gösterip göstermediğini anlamak için asimetri (skewness) ve basıklık (kurtosis) katsayılarına ve bunların kritik oran değerlerine bakılmıştır. Asimetri ve basıklık değerleri -2 ile +2 arasında ise verilerin normal dağılım gösterdiği kabul edilmektedir (Bayram, 2010). 
Entelektüel sermaye ölçeği birinci düzey DFA modeline ilişkin uyum iyiliği değerlerinin yeterli düzeyde olduğu görüldükten sonra ikinci düzey DFA yapılmıştır. Entelektüel sermaye ölçeğinin birinci düzey DFA'da entelektüel sermaye bileşenleri aralarında ilişkiler olacak şekilde birer örtük değişken olarak modele dahil edilmişti, ikinci düzey DFA'da ise yapısal sermaye, ilişkisel sermaye ve insan sermayesi, entelektüel sermaye üst örtük değişkenine bağlanmıştır. Entelektüel sermaye ölçeği ikinci düzey DFA modeline ilişkin uyum iyiliği değerlerinin ( $\chi 2 / \mathrm{sd}$ : 2,357; GFI: 0,918; AGFI: 0,892; RMSEA: 0,056; CFI: 0,921; IFI: 0,922) yeterli düzeyde olduğu (Jöreskog ve Sörbom 1993; Kline, 2005) ve tüm ikili ilişkilerin istatistiksel olarak anlamlı $(p<0,01)$ olduğu görülmektedir. Model gerekli uyum iyiliği değerlerini sağlasa da değişkenlerin karşılıklı etkilerinin istatistiksel açıdan anlamlı olup olmadığına da bakılmalıdır. Ayrıca tüm ikili ilişkilerin istatistiksel olarak anlamlı $(p<0,01)$ olduğu görülmektedir. Faktör yüklenimlerini gösteren standardize edilmiş regresyon katsayıları incelendiğinde; yapısal sermaye örtük değişkenini açıklayan gözlenen değişkenlerin faktör yükleri 0,526 ile 0,789 arasında, ilişkisel sermaye örtük değişkeninin açıklayan gözlenen değişkenlerin faktör yükleri 0,509 ile 0,777 arasında ve insan sermayesi örtük değişkenini açıklayan gözlenen değişkenlerin faktör yükleri ise 0,630 ile 0,876 arasında değişmektedir. Ayrıca entelektüel sermaye bileşenlerinden yapısal sermayenin faktör yüklenimi 0,665, ilişkisel sermayenin faktör yüklenimi 0,505, insan sermayesinin faktör yüklenimi ise en yüksek değer olan 0,698 olduğu görülmektedir. Dolayısıyla entelektüel sermayeyi açıklamada en fazla etkiye sahip bileşen insan sermayesidir. Bunlara göre entelektüel sermaye ölçeğine ait ikinci düzey DFA modeli, kabul edilebilir uyum değerlerini gösterdiği gibi tüm örtük değişkenlere ait faktör yüklenimleri yeterli ve istatistiksel açıdan anlamdır.

Yenilikçilik ölçeği DFA modeline ilişkin uyum iyiliği değerlerinin (X2/sd: 2,502; GFI: 0,991; AGFI: 0,960; RMSEA: 0,060; CFI: 0,994; IFI: 0,922) yeterli düzeyde olduğu (Jöreskog ve Sörbom 1993; Kline, 2005) ve tüm ikili ilişkilerin istatistiksel olarak anlamlı $(p<0,01)$ olduğu görülmektedir. Faktör yüklenimlerini gösteren standardize edilmiş regresyon katsayıları incelendiğinde; yenilikçilik örtük değişkenini açıklayan gözlenen değişkenlerin faktör yükleri 0,494 ile 0,903 arasında değişmektedir. Dolayısıyla yenilikçilik değişkeninin açıklamada en fazla etkiye sahip gözlenen değişken; "Geliştirilen iş süreçleri firmamıza önemli katkılar sağlamıştır". Bunlara göre yenilikçilik ölçeğine ait birinci düzey DFA modeli, kabul edilebilir uyum değerlerini gösterdiği gibi tüm faktör yüklenimleri yeterli ve istatistiksel açıdan anlamdır.

Örgüt performansı ölçeği DFA modeline ilişkin uyum iyiliği değerlerinin $(\chi 2 / s d: 4,472 ; G F I: 0,971$; AGFI: 0,914; RMSEA: 0,073; CFI: 0,994; IFI: 0,922) yeterli düzeyde olduğu (Jöreskog ve Sörbom 1993; Kline, $2005)$ ve tüm ikili ilişkilerin istatistiksel olarak anlamlı $(p<0,01)$ olduğu görülmektedir. Faktör yüklenimlerini gösteren standardize edilmiş regresyon katsayıları incelendiğinde; örgüt performansı örtük değişkenini açıklayan gözlenen değişkenlerin faktör yükleri 0,487 ile 0,865 arasında değişmektedir. Dolayısıyla örgüt performansı değişkeninin açıklamada en fazla etkiye sahip gözlenen değişken; "Yatırımlarımızın getirisi rakiplerimizden daha yüksektir". Bunlara göre örgüt performansı ölçeğine ait birinci düzey DFA modeli, kabul edilebilir uyum değerlerini gösterdiği gibi tüm faktör yüklenimleri yeterli ve istatistiksel açıdan anlamdır.

Ölçüm araçlarının geçerliliği tespit edildikten sonra faktör yapısına uygun olarak ortaya çıkan örtük değişkenlerin güvenilirliği, güvenilirlik ölçmede kullanılan Cronbach Alfa katsayısı ile ölçülmüştür. Örtük değişkenlerin Cronbach Alfa güvenilirlik katsayısı ve gözlenen değişken sayısı Tablo 1'de gösterilmektedir.

Tablo 1. Örtük Değişkenlerin Güvenilirlik Değerleri

\begin{tabular}{|l|c|c|}
\hline Örtük Değişken & Cronbach Alfa Katsayısı & Gözlenen Değişken Sayısı \\
\hline Entelektüel Sermaye & 0,898 & 21 \\
\hline Yenilikçilik & 0,815 & 5 \\
\hline Örgüt Performansı & 0,798 & 6 \\
\hline
\end{tabular}


Tablo 1'den anlaşıldığı gibi tüm örtük değişkenlerin Cronbach Alfa katsayıları eşik değer olan 0,60'den büyük olduğu için söz konusu örtük değişkenlerin güvenilirliklerinin yüksek olduğu (Karagöz, 2016) görülmektedir.

\subsection{Hipotezlerin Testi}

Değişkenler arasındaki ilişkileri belirlemek için korelasyon analizi yapılmıştır. Korelasyon analizinin yapılabilmesi için değişkenler arasında doğrusal bir ilişkinin olması gerekir. Bunun için de öncelikle Serpilme diyagramı çizdirilerek, değişkenler arasındaki doğrusal ilişkinin varlığı tespit edilmiştir. Tablo 2'de örtük değişkenler arasındaki doğrusal ilişkiyi gösteren Pearson korelasyon katsayıları $(r)$ verilmiştir.

Tablo 2. Korelasyon Tablosu

\begin{tabular}{|lrrccc|}
\hline Örtük Değişkenler & Ortalama & St. Sapma & $\mathbf{1}$ & $\mathbf{2}$ & $\mathbf{3}$ \\
1. Entelektüel Sermaye & 3,726 & 0,0514 & 1 & $0,490^{* *}$ & $0,405^{* *}$ \\
2. Yenilikçilik & 3,542 & 0,0637 & $0,490^{* *}$ & 1 & $0,382^{* *}$ \\
3. Örgüt Performansı & 4,020 & 0,0484 & $0,405^{* *}$ & $0,382^{* *}$ & 1 \\
\hline${ }^{* *} p<0,01$ & & & & &
\end{tabular}

Tablo 2 inncelendiğinde tüm örtük değişkenler arasındaki ilişkilerin, istatistiksel açıdan anlamlı olduğu görülmektedir. Ayrıca bağımsız değişkenler arasındaki ilişkilerin düzeyi 0,70'den küçük olduğu için çoklu bağlantı problemi varlığından bahsedilemez (Karagöz, 2016).

Şekil 2'de görüldüğü gibi entelektüel sermaye, yenilikçilik ve örgüt performansı arasındaki nedensel ilişkiler YEM ile yol analizi kullanılarak gerçekleştirilmiştir. Şekil 2'de entelektüel sermaye, yapısal, ilişkisel ve insan sermayesi bileşenlerinden meydana gelen, yeterli uyum iyiliği değerlerine sahip ikinci düzey DFA modeli kullanılan bir bağımsız-örtük değişken olarak ele alınmıştır. Yenilikçilik entelektüel sermaye ile ilişkisinde bağımlı bir değişken iken, örgüt performansı ile ilişkisinde ise bağımsız bir değişken olarak modelde yer almakta olup aynı zamanda yeterli uyum iyiliği değerlerine sahip yenilikçilik ölçeği birinci düzey DFA modeli kullanılmıştır.

Araştırmanın yapısal eşitlik modelinde bağımlı değişken olan örgüt performansı örtük değişkeni olarak, yeterli uyum iyiliği değerleri gösteren örgüt performansı ölçeği birinci düzey DFA modeli kullanılmıştır.

Şekil 2'den araştırmanın yapısal eşitlik modelinin yeterli (X2/sd: 2,062; GFI: 0,908; AGFI: 0,894; RMSEA: 0,051; CFI: 0,920; IFI: 0,911) uyum iyiliği değerlerine sahip olduğu (Jöreskog ve Sörbom 1993; Kline, 2005) anlaşılmaktadır. Bu bulgu araştırmanın yapısal eşitlik modelinin veri yapısına uygun olarak doğrulandığına işaret etmektedir. 
Şekil 2. Araştırmanın Yapısal Eşitlik Modeli

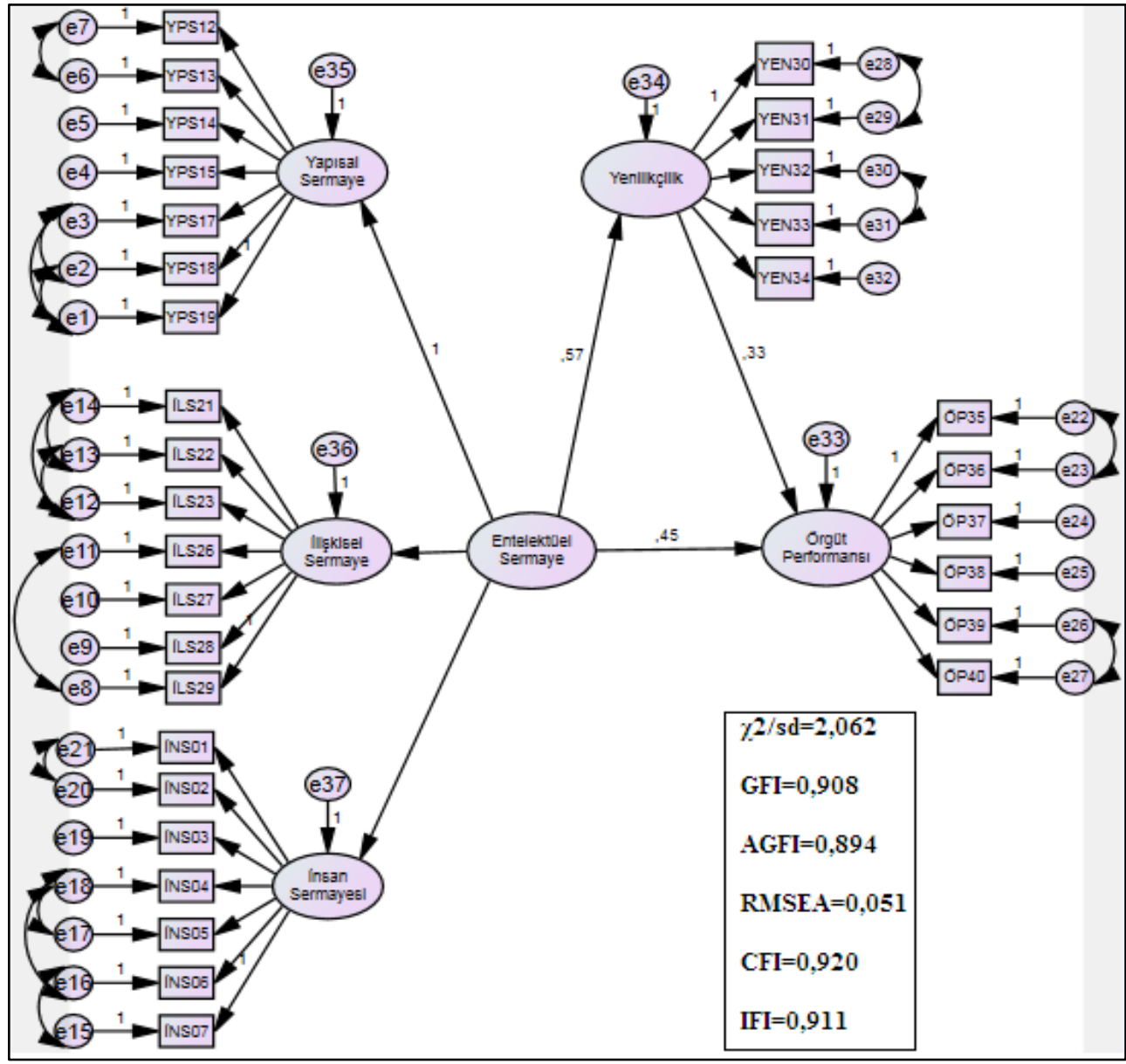

Değişkenler arasındaki standardize edilmiş regresyon katsayıları ( $\beta$ ), anlamlılık düzeyleri $(p)$ ve belirlilik katsayılarını gösteren tahmin değerleri $\left(R^{2}\right)$ Tablo 3'de verilmiştir.

Tablo 3. Araştırmanın Yapısal Eşitlik Modeline Ait Tahmin Değerleri

\begin{tabular}{|c|c|c|c|c|c|}
\hline Değişkenler & & & $\begin{array}{c}\text { Standardize Edilmiş } \\
\text { Regresyon Katsayıları }(\beta)\end{array}$ & $\mathbf{R}^{2}$ & $\mathbf{P}$ \\
\hline Yenilikçilik & $<--$ & Entelektüel Sermaye & 0,574 & 0,329 & $* * *$ \\
\hline Örgüt Performansı & $<--$ & Entelektüel Sermaye & 0,449 & \multirow[b]{2}{*}{0,216} & 0,003 \\
\hline Örgüt Performansı & $<--$ & Yenilikçilik & 0,332 & & 0,031 \\
\hline
\end{tabular}

Tablo 3'den görüldüğü gibi entelektüel sermayenin örgüt performansı üzerinde pozitif ve anlamlı bir etkisinin $(\beta=0,449 ; p<0,01)$ olduğu anlaşılmaktadır. Bu bulguya göre, "Deniz ulaştırma işletmelerinde entelektüel sermaye, örgüt performansını pozitif ve anlamlı yönde etkiler" şeklindeki hipotez kabul edilmiştir. Bunun dışında entelektüel sermaye, yenilikçilik ile birlikte örgüt performansındaki değişimin \%21,6’nı açıklamaktadır. Tablo 3 incelendiğinde entelektüel sermayenin yenilikçilik üzerinde pozitif ve anlamlı bir etkisinin $(\beta=0,574 ; p<0,01)$ olduğu anlaşılmaktadır. Bu bulguya göre, "Deniz ulaştırma işletmelerinde entelektüel sermaye, yenilikçiliği pozitif ve anlamlı yönde etkiler" şeklindeki hipotez kabul edilmiştir. Ayrıca entelektüel sermaye yenilikçilikteki değişimin \%32,9'nu açıklamaktadır. Yenilikçilik ve örgüt performansı arasındaki ilişkiye bakıldığında, yenilikçiliğin örgüt performansı üzerinde, entelektüel sermaye kadar olmasa da pozitif ve anlamlı bir etkisinin olduğu $(\beta=0,332 ; p<0,05)$ görülmektedir. Buna göre, "Deniz ulaştırma 
işletmelerinde yenilikçilik, örgüt performansını pozitif ve anlamlı yönde etkiler" şeklindeki hipotez kabul edilmiştir.

Aynı anda birden fazla regresyon analizlerinin yapılabildiği YEM analizlerinde, değişkenler arasındaki doğrudan, dolaylı ve toplam etkiler ortaya çıkartılabilmektedir. Burada toplam etki, doğrudan ve dolaylı etkilerin toplamından oluşmaktadır. YEM'in bu özelliği sayesinde değişkenler arasındaki aracılık etkisi bulunabilir çünkü bir değişkenin başka bir değişken üzerindeki dolaylı etkisi ancak başkaca bir değişken tarafından sağlanabilir. Bu kapsamda araştırmanın amacına yönelik olarak, temel değişkenler arasındaki toplam, doğrudan ve dolaylı etkiler de analiz edilmiş ve Tablo 4'de gösterilmiştir.

Tablo 4. Temel Değişkenler Arasındaki Toplam, Doğrudan ve Dolaylı Etkiler

\begin{tabular}{|lclccc|}
\hline \multicolumn{1}{|c}{ Değişkenler } & & & $\begin{array}{c}\text { Toplam } \\
\text { Etki }\end{array}$ & $\begin{array}{c}\text { Doğrudan } \\
\text { Etki }\end{array}$ & $\begin{array}{c}\text { Dolaylı } \\
\text { Etki }\end{array}$ \\
Yenilikçilik & $<---$ & Entelektüel Sermaye & 0,574 & 0,574 & - \\
Örgüt Performansı & $<---$ & Entelektüel Sermaye & 0,530 & 0,449 & 0,081 \\
Örgüt Performansı & $<---$ & Yenilikçilik & 0,332 & 0,332 & - \\
\hline
\end{tabular}

Tablo 4 incelendiğinde entelektüel sermayenin, örgüt performansı üzerinde $(\beta=0,449 ; p<0,01)$ doğrudan etkisinin yanında $(\beta=0,081 ; p<0,01)$ dolaylı bir etkisinin de olduğu anlaşılmaktadır. Entelektüel sermayenin örgüt performansı üzerindeki bu dolaylı etkisinin, yenilikçilik değişkeni aracılığı ile olabileceğini işaret etmektedir. Bu noktadan hareketle entelektüel sermaye ve örgüt performansı arasında yenilikçiliğin aracılık etkisini ortaya çıkartmak için ara değişken testi yapılmıştır.

Aracılık testi, literatürde çoklukla Baron ve Keny (1986) çalışmasında belirtilen dört koşulun sağlanmasına göre yapılmaktadır. Bu kapsamda aracılık testi için iki model oluşturulmuştur. Birinci model entelektüel sermayenin örgüt performansı üzerindeki toplam etkisini belirlemek için kurulmuştur. Bu modelin uyum iyiliği değerleri yeterli değerleri arasındadır. Ayrıca entelektüel sermayenin örgüt performansı üzerinde pozitif ve anlamlı bir etkisi olduğu ve tek başına örgüt performansındaki değişim \%19,3'nü açıkladığı $\left(\beta=0,530 ; p<0,01 ; R^{2}=19,3\right)$ anlaşılmaktadır. Dolayısıyla bu bulgulara göre Baron ve Kenny (1986) tarafından belirlenen aracılık etkisinin birinci koşulu sağlanmıştır. İkinci ve üçüncü koşulun oluşup oluşmadığını görebilmek için entelektüel sermaye ve örgüt performansı arasındaki ilişkiye, Şekil 2'de gösterildiği gibi yenilikçilik değişkeni dahil edilmiştir. Daha önceden belirtildiği gibi modelin uyum iyiliği değerlerinin Şekil 2'den ve Tablo 3'den yeterli seviyede olduğu anlaşılmaktadır. Buradaki standardize edilmiş regresyon katsayıları entelektüel sermayenin ve yenilikçiliğin, örgüt performansı üzerindeki doğrudan etkisini göstermektedir. Bu bulgular göre, Baron ve Kenny (1986) tarafından ara değişken etkisinde belirlenen ikinci ve üçüncü koşulları da sağlanmıştır.

Entelektüel sermaye ve örgüt performansı arasındaki ilişkiye yenilikçiliğin dâhil edilmesiyle, entelektüel sermayenin standardize edilmiş regresyon katsayısının $(\beta=, 530)^{\prime}$ dan $(\beta=, 449)^{\prime}$ a düştüğü ve yenilikçiliğin bir kısım etkiyi $(\beta=, 081)$ kendi üzerine aldığı Tablo 4 'den görülmektedir. Ayrıca bu iki değişkenin birlikte örgüt performansı üzerindeki değişimin $\% 21,6^{\prime} n ı\left(R^{2}\right)$ açıkladığı ve $R^{2}$ 'deki bu değişim istatistiksel $(0,01)>p$ olarak da anlamlı olduğu anlaşılmaktadır. Yenilikçilik modele eklendikten sonra, entelektüel sermayenin örgüt performansı üzerindeki etkisinin azalması fakat etkisinin istatiksel anlamda hala devam etmesi, yenilikçiliğin bu ilişkide kısmi ara değişken etkisinin olduğuna işaret eder. Dolayısıyla bu bulgu, Baron ve Kenny (1986) tarafından ara değişken etkisinde belirtilen dördüncü koşulunun da sağlandığını göstermektedir. Bunların dışında da ara değişken etkisinin istatistiksel açıdan anlamlı olup olmadığına bakılması gerekmektedir. Diğer bir ifade ile yenilikçiliğin modele alınmasıyla entelektüel sermayenin örgüt performansı üzerindeki etkisini gösteren regresyon katsayısında meydana gelen azalmanın anlamlı olup olmadığının test edilmesi gerekir. 
Son aşamada ise ara değişken etkisinin istatistiksel açıdan anlamlılığını test etmek için Sobel testi yapılmıştır. Sobel testinin alternatif hipotezi olan "Ara değişken etkisi vardır" test etmek için, ara değişken olan yenilikçiliğin standardize edilmemiş regresyon katsayıları ve bunların standart hatalarıyla, Preacher ve Leonardelli (2017) tarafından geliştirilen interaktif hesaplama programı kullanılarak kısmi aracılık etkisinin anlamlı (Sobel $z=3,3835 ; p<0,01$ ) olduğu görülmüştür. Bu bulgulardan yola çıkarak, "Deniz ulaştırma işletmelerinde entelektüel sermaye ve örgüt performansı arasındaki ilişkide, yenilikçiliğin ara değişken etkisi vardır", şeklindeki hipotez kabul edilmiştir.

\section{Tartışma ve Sonuç}

Küresel rekabet ortamında faaliyette bulunan deniz ulaştırma işletmelerinin yürüttüğü deniz ulaştırması diğer ulaştırma türlerine göre daha düşük maliyetli ve büyük miktarlardaki yükleri tek bir seferde taşıyabilme özelliğine sahip olduğu için de en fazla talep edilen ulaştırma türüdür. Dolayısıyla deniz ulaştırma faaliyetleri, uluslararası ticaretin gerçekleşmesinde önemli bir yere sahiptir. Bu noktadan hareketle, küresel ve dinamik rekabet ortamında faaliyette bulunan deniz ulaştırma işletmelerinin sahip olduğu maddi olmayan ve rekabette üstünlük sağlayan kaynaklardan entelektüel sermayelerinin, bu işletmelerdeki yöneticilerin bakış açılarına göre ölçülmesi ve entelektüel sermaye, örgüt performansı ve yenilikçilik arasındaki nedensel ilişkilerin belirlenmesi ve bu ilişkide yenilikçiliğin ara değişken rolünün olup olmadığının ortaya çıkartılması bu çalışmanın amacını oluşturmaktadır.

Çoğunluğunu kuru yük gemi işletmeciliği yapan deniz ulaştırma işletmelerindeki erkek yöneticilerin oluşturduğu örneklemden anket yöntemiyle elde edilen veriler ile ölçüm aracının yapısal geçerliliğini test etmek için AFA ve DFA yapıımıştır. AFA soncunda oluşan değişken yapısı DFA ile doğrulanmış ve sonrasında güvenilirliği tespit etmek için yapılan analizde ölçüm aracının güvenilir olduğu ortaya çıkmıştır. Diğer bir ifade ile veri toplamak için kullanılan anketlerin geçerli ve güvenilir olduğu anlaşılmıştır.

Araştırma modeli, entelektüel sermayenin bileşenlerini ve entelektüel sermayenin örgüt performansı üzerindeki doğrudan ve yenilikçilik aracılıyla dolaylı etkilerini içermektedir. Yapısal eşitlik modellemesi ile yol analizi kullanılarak test edilen araştırma modelinin uyum iyiliği değerlerinin yeterli uyum iyiliği değerlerine sahip olduğu anlaşılmaktadır. Bu bulgular araştırma kapsamındaki deniz ulaştırma işletmelerinin sahip olduğu entelektüel sermayenin örgüt performanslarını artırdığını ve aynı zamanda entelektüel sermayenin işletme yenilikçiliğini artırarak da örgüt performansını artırdığını gösteren araştırma modelini doğrulamaktadır.

Entelektüel sermaye ve örgüt performansı ile ilgili hipotezlerin testi için yapılan yapısal eşitlik modellemesi ile yol analizlerinde, entelektüel sermayenin örgüt performansı üzerinde pozitif ve anlamlı bir etkisi olduğu ve tek başına örgüt performansındaki değişim \%19,3’nü açıkladığı $\left(\beta=0,530 ; p<0,01 ; R^{2}=19,3\right)$ yenilikçilik ile birlikte $\left(\beta=0,449 ; p<0,01 ; R^{2}=21,6\right) \% 21,6$ 'sını açıkladığı tespit edilmiştir. Başka bir deyişle örgüt performansının \%19,3' ü tek başına entelektüel sermayeye, $\% 21,6^{\prime}$ sı ise entelektüel sermaye ile yenilikçiliğe bağlıdır. Bu bulgulara göre Hipotez 1 kabul edilmiştir. Entelektüel sermayenin bütün olarak örgüt performansı üzerinde önemli bir etkiye sahip olduğunun deniz ulaştırma işletmelerindeki yöneticiler tarafından da ortaya konulması farklı sektörleri konu alan (Pena, 2002; Cabrita ve Vaz, 2006; Hong vd., 2008; Sharabati vd., 2010; Yıldız, 2011; Cezlan, 2015) çalışmaları desteklemektedir.

Entelektüel sermaye ve yenilikçilik ile ilgili hipotezlerin testi için yapılan YEM ile yol analizlerinde, entelektüel sermayenin yenilikçilik üzerinde pozitif ve anlamlı bir etkisi olduğu ve tek başına örgüt performansındaki değişim \%32,9' unu açıkladığı $\left(\beta=0,574 ; p<0,01 ; R^{2}=32,9\right)$ tespit edilmiştir. Bu bulguya göre Hipotez 2 kabul edilmiştir. Entelektüel sermayenin bütün olarak yenilikçilik üzerinde önemli bir etkiye sahip olduğunun deniz ulaştırma işletmelerindeki yöneticiler tarafından da ortaya konulması farklı sektörleri konu alan (Subramaniam ve Youndt, 2005; Santos-Rodrigues vd., 2013; Cezlan, 2014) çalışmaları desteklemektedir.

Yenilikçilik ve örgüt performansı ile ilgili hipotezin testi için yapılan yapısal eşitlik modellemesi ile yol analizinde, yenilikçiliğin örgüt performansı üzerinde, entelektüel sermayeden daha düşük pozitif ve anlamlı bir etkisi olduğu $(\beta=0,332 ; p<0,01)$ tespit edilmiştir. Bu bulguya göre Hipotez 3 kabul edilmiştir. Bu bulgu farklı sektörler üzerinde yapılan (Damanpour vd., 1989; Jin vd., 2004; Zehir ve Özşahin 2006; Özer ve Akça 2007; Damanpour vd., 2009; Ruiz-Arroyo vd., 2012; Eren ve Kaplan, 2014) çalışmaları desteklemektedir. 
Yenilikçiliğin örgüt performansı üzerinde, entelektüel sermayeye göre daha düşük bir etkisinin olması, deniz ulaştırma işletmelerinde yenilikçiliğin daha ziyade yeni teknolojilere uyum sağlama ve operasyonel süreçlerde kullanma şeklinde gerçekleşmesi ile açıklanabilir. Bunu yanında deniz ulaştırmasında müşteri konumunda olan taşıtanların veya yük sahiplerinin beklenti ve ihtiyaçlarını karşılayacak yenilikçi yaklaşımlarda bulunmak, bunları kullanmak ve teknolojik yeniliklerin takip etmek örgüt performansını artırıcı bir unsurdur.

Entelektüel sermaye ve örgüt performansı arasındaki ilişkide yenilikçiliğin ara değişken etkisini ortaya çıkartmak için yapılan yapısal eşitlik modellemesi ile ara değişken analizinde, yenilikçiliğin kısmı ara değişken etkisinin ve bu etkinin de istatistiksel açıdan (Sobel $z=3,3835 ; p<0,01$ ) anlamlı olduğu tespit edilmiştir. Bu bulgu daha önce yapılmış bazı (Bontis vd., 2000; Youndt vd., 2004; Cezlan, 2014) çalışmalarla paralellik göstermektedir. Entelektüel sermaye ile örgüt performansı arasındaki ilişkide yenilikçiliğin kısmi ara değişken etkisine sahip olması, deniz ulaştırma işletmelerinin sahip olduğu entelektüel sermayenin örgüt performansını doğrudan etkilediği gibi aynı zamanda yenilikçilik üzerinden de dolaylı etkilediğini göstermektedir. Entelektüel sermayenin iyi yönetilmesi hem yenilikçilik üzerinden dolaylı hem de doğrudan örgüt performansını artıracaktır.

Özetle, elde edilen bulgular toplu olarak değerlendirildiğinde, deniz ulaştırma işletmelerinin örgüt performansı üzerinde, entelektüel sermayenin olumlu etkisinin olduğu; öte yandan, örgüt performansı üzerinde kısmi ara değişken etkisi olmakla birlikte yenilikçilik eklendiği koşulda, örgüt performansı ve entelektüel sermaye arasındaki ilişkinin daha da güçlendiği sonucuna ulaşılmıştır. Bir başka deyişle, sadece entelektüel sermaye değil, yenilikçilik ile birlikte entelektüel sermayenin yaratacağı olumlu etki, örgüt performansının gelişmesi üzerinde daha fazla etkili olacağını göstermektedir.

Bunlara göre, deniz ulaştırma işletmelerindeki yöneticilere; öncelikle çalışanlarının bilgi, beceri ve yeteneklerini geliştirici uygulamalar yapmalarını ve örgüt içinde bilgi paylaşımını ve öğrenmeyi özendirici bir yönetim anlayışının yerleşmesini sağlamalarını ayrıca paydaşlarıyla ilişki ağlarını güçlendirici bir yaklaşım sergilemelerinin entelektüel sermayelerini artırarak örgüt performanslarının artıracağını ve aynı zamanda yenilikçi çözümler üreterek de örgüt performanslarının artacağı söylenebilir. Entelektüel sermayesini yenilikçiliğini geliştirmek için kullanan deniz ulaştırma işletmelerindeki yöneticiler, entelektüel sermayenin örgüt performansı üzerindeki etkisini artıracaktır. Dolaysıyla deniz ulaştırma işletmelerindeki yöneticiler, işletmelerinin sahip olduğu entelektüel sermayeyi etkili ve verimli yöneterek yenilikçi bir örgüt yapısına ve yüksek bir örgüt performansına ulaşabileceklerdir. Birbirine yakın veya benzer finansal ve fiziksel kaynakları olan işletmelerden, başarılı olan işletmeleri başarısız olan işletmelerden ayıran en önemli unsurlar; başarıı olan işletmelerin sahip olduğu entelektüel sermayelerinin değeri, bu entelektüel sermayelerini etkili yönetme becerileri ve yenilikçi yaklaşımlardır.

ileride yapılacak araştırmalarda, entelektüel sermayenin (insan, yapısal ve ilişkisel sermaye) ve yenilikçiliğin (yönetsel ve teknik yenilikçilik) boyutları açısından ve deniz ulaştırma işletmeleri belirli faaliyet alanlarına ayırarak örneğin; konteyner, Ro/Ro veya kuru yük taşımacılığı gibi söz konusu ilişkileri ve araştırma modelini test etmelerini ve ayrıca araştırma modelinin geliştirilmesi için entelektüel sermaye ve örgüt performansı arasındaki ilişkide etkili olabilecek örneğin; bilgi yönetimi, örgütsel öğrenme ve örgüt yapısı gibi başka örgütsel kavramları da incelemeleri önerilebilir.

Araştırma belli bir sektörde ve sınırlı bir örneklem kullanılarak gerçekleştirilmiştir. Buna göre araştırmanın bulguları, araştırmanın örneklemi olan Türkiye'de faaliyet gösteren 500 gros ton ve üzeri gemi işletmeciliği yapan deniz ulaştırma işletmelerindeki yöneticilerle sınırlıdır. Dolayısıyla araştırma verilerinden elde edilen bulgular, örnekleme göre farklııık gösterebileceğinden farklı sektörler için de araştırma modeli test edilmelidir. 


\section{Kaynaklar}

Altunoğlu, E. A., \& Demir, N. (2012). Konaklama işletmelerinde entelektüel sermaye bileşenlerinin incelenmesi: Kuşadası örneği. Atatürk Üniversitesi Iktisadi ve Idari Bilimler Dergisi, 26(2), 297-312.

Armbruster, H., Bikfalvi, A., Kinkel, S., \& Lay, G. (2008). Organizational innovation: The challenge of measuring nontechnical innovation in large-scale surveys, Technovation, 28, 644-657.

Baron, R. M., \& Kenny, D. A. (1986). The moderator-mediator variable distinction in social psychological research: conceptual, strategic, and statistical considerations, Journal of Personality and Social Psychology, 51, 1173-1182.

Baş, M., Yangil, M., \& Aygün, S. (2014). Entelektüel sermaye alanında yapılan lisansüstü tez çalışmalarına yönelik bir içerik analizi: 2002-2012 dönemi. Uluslararası Yönetim iktisat ve Işsletme Dergisi , 10(23), 207-226.

Bayram, N. (2010). Yapısal eşitlik modellemesine giriş (AMOS uygulamaları) (1.baskı). Bursa: Ezgi Kitabevi.

Beattie, V., \& Thomson, S. J. (2007). Lifting the lid on the use of content analysis to investigate intellectual capital disclosures. Accounting forum, 31(2), 129-163.

Becheikh, N., Landry, R., \& Amara, N. (2006). Lessons from Innovation empirical studies in the manufacturing sector: A systematic review of the literature from 1993-2003. Technovation, 28, 644-664.

Bontis, N. (1998). Intellectual capital: an exploratory study that develops measures and models, Management decision, 36(2), 63-76.

Bontis, N., Keow, W. C. C., \& Richardson, S. (2000). Intellectual capital and business performance in Malaysian industries. Journal of Intellectual Capital, 1(1), 85-100.

Bowen, F., Rostami, M., \& Piers, S. (2009). Timing is everything: A meta- analysis of the relationships between organizational performance and Innovation. Journal of Business Research, 11(63), 1179-1185.

Bozbura, F., \& Toraman, A. (2004). Türkiye'de entelektüel sermayenin ölçülmesi ile ilgili model çalışması ve bir ugulama. iTÜ Mühendislik Dergisi, 3(1), 55-56.

Bölükbaşı, Y. (2014). Entelektüel sermaye ölçülmesinde kullanılan yöntemler ve sigorta sektöründe bir araştırma. Marmara Üniversitesi iiBF Dergisi, 36(1), 425-427.

Büyüköztürk, Ş. (2007). Sosyal bilimler için veri analizi el kitabı: İstatistik, araştırma deseni, SPSS uygulamaları ve yorum. Ankara: Pegem Akademi Yayıncılık.

Bryman, A., \& Cramer, D. (2001). Quantitative data analysis with SPSS release 10 for windows: A guide for social scientists. East Sussex: Routledge.

Cabrita, M., \& Vaz, J. L. (2005). Intellectual capital and value creation: Evidence from the Portoguese banking industry. The Electronic Journal of Knowledge Management, 4(1), 11-20.

Cezlan, Ç. (2014). Entelektüel sermayenin firma yenilikçiliği ve firma performansına etkisi: sağlık işletmelerine yönelik bir uygulama. Beykent Üniversitesi Sosyal Bilimler Enstitüsü, Yayınlanmamış Doktora Tezi, İstanbul.

Cezlan, Ç. (2015). Effect of intellectual capıtal on company innovatıon: A research for health administration. Academy of Strategic Management Journal, 14, 21-32.

Chapman, R. L., Soosay, C., \& Kandampally, J. (2002). Innovation in logistic services and the new business model: A conceptual framework. Managing Service Quality, 12(6), 358-371.

Chen, Y. S. (2008). The positive effect of green intellectual capital on competitive advantages of firms. Journal of Business Ethics, 77(3), 271-286.

Damanpour, F., \& Evan, W. (1984). Organizational innovation and performance: The problem of "organizational lag". Administrative Science Quarterly, 29(3), 392-409.

Damanpour, F., Szabat, K. A., \& Evan, W.M. (1989). The relationship between types of innovation andorganizational performance. Journal of Management Studies, 26(6), 587-601.

Damanpour, F., Walker, R., \& Avellaneda, C. (2009). Combinative effects of innovation types and organizational performance: A longitudinal study of service organizations. Journal of Management Studies, 46(4), 650-675.

Daugherty, P. J., Chen, H., \& Ferrin, B. (2011). Organizational structure and logistics service innovation. The International Journal of Logistics Managment, 22(1), 26-51.

Desphande, R., \& Farley, J. U. (2003). High performance firms in a complex new China. Journal of Global Marketing. 16(1), 217-228.

Deniz Ticareti, (2017). Rakamlarla denizcilik sektörü ve istatistikler. İstanbul: IMEAK. 
Edvinsson, L., \& Malone, M. S. (1997). Intellectual capital: Realizing your company's true value by finding its hidden brainpower. New York: Harper business.

Elçi, Ş. (2007). İnovasyon kalkınmanın ve rekabetin anahtarı (2. Baskı). Ankara: Technopolis Group.

Elçi, Ş. (2010). İnovasyonun ihmal edilen türleri: Hizmet, organizasyon ve pazarlama inovasyonu. Bakış Açısı Dergisi, 66, 37-46.

Eraslan, H., Bulu, M., \& Bakan, ì. (2008), Kümelenmeler ve inovasyona etkisi: Turizm sektöründe uygulamalar. SOiD Seyahat ve Otel İşletmeciliği Dergisi, 5(3), 15-50.

Ercan, M. K., Öztürk, M. B., \& Demirgüneş, K. (2003). Değere dayalı yönetim ve entelektüel sermaye. Ankara: Gazi Kitabevi.

Eren, M., Yücel, R., \& Eren, S. (2010). Firma performansına etkileri kapsamında çevresel olumsuzluk, pazar dinamizmi, müşteri odaklılık ve yenilikçilik arasındaki ilişkilerin incelenmesi. Journal of Yaşar University, 18(5), 3102-3116.

Eren, M. Ş., \& Kaplan, M. (2014). Kurumsal yetkinliklerin örgütsel performans üzerindeki etkileri: Üretim firmaları. Dumlupınar Üniversitesi Sosyal Bilimler Dergisi, 40, 174-192.

Erkuş, A. (2007). Entelektüel sermayenin örgüt performansına etkisi: Savunma sanayisinde bir araştırma. Kara Harp Okulu Savunma Bilimleri Dergisi, 6(1), 86-113.

Foxall, R. (1988). Marketing new technology: Markets, hierarchies, and user-initiated innovation. Managerial and Decision Economics, 9(3), 237-250.

Fuentes-Fuentes, M., Albacete-Saez, C., \& Llorens-Montes, F. (2004). The impact of environmental characteristics on TQM principles and organizational performance. Omega-International Journal of Management Science, 32(6), 425-442.

Gonzalez-Benito, O., \& Gonzalez-Benito, J. (2005). Cultural vs. operational market orientation and objective, subjective performance, perspective of production and operations. Industrial Marketing Management, 34, 797-829.

Hong, R.-Y., Wu, X.-B., \& Peng, X., 2008, Intellectual capital and firm performance in Chinese creative industry firms. IEEE IEEM, 867-871.

Isaac, R. G., Herremans, I. M., \& Kline, T. J. (2010). Intellectual capital management enablers: A structural equation modeling analysis. Journal of Business Ethics, 93, 373-391.

Jin, Z., Hewitt-Dundas, N., \& Thompson, N. J. (2004). Innovativeness and performance: Evidence from manufacturing sectors. Journal of Strategic Marketing, 12, 255-266.

Johne, A. (1999). Succesful market innovation. European Journal of Innovation Management, 2(1), 6-11.

Jöreskog, K. G., \& Sörbom, D. (1993). LISREL 8: Structural equation modeling with the SIMPLIS command language. Scientific Software International.

Kaplan, R., \& Norton, D. (1996). Translating strategy into action, the balanced scorecard. Boston, Massachusetts: Harvard Business School Press.

Karakaş, A., Öz, Y., \& Yıldız, R. M. (2017). The effect of innovatıon activities on organizational performance: A research on hotel businesse. Journal of Recreation and Tourism Research, 4(1), 49-59.

Kelley, T., \& Littman, J. (2005). The ten faces of innovation: IDEO's strategies for defeating the devil's advocate and driving creativity throughout your organization, currency. USA: Doubleday.

Koçoğlu, İ., İmamoğlu, Z. S., \& İnce, H. (2009). The relationship between firm intellectual capital and the compettive advantage. Journal of Global Strategic Management, 181-208.

Kurgun, O. A., \& Akdağ, G., 2013, Entelektüel sermaye ve örgüt performansı ilişkisi: Akdeniz bölgesindeki otel işletmelerinde bir araştırma. Nevsehir University Journal of Social Sciences, 2, 155-176.

Kutukiz, D., \& Tunçbilek, M. (2008). Küreselleşeme sürecinde firma değeri ve yönetim sürecindeki değişimler. Journal of Azerbaijani Studies, 18-26.

Kline, P. (1994). An easy guide to factor analysis. New York, NY: Routledge.

Klein, D. F. (2005). Beyond significance testing: Reforming data analysis methods in behavioral research. American Journal of Psychiatry, 162(3), 643-659.

Low, L. (2009). Innovation for development and the role of government: A perspective from the east asia and pacific region. Asian-Pacific Economic Literature, 23(2), 128-129.

Meydan, H., \& Şeşen, H. (2011). Yapısal eşitlik modellemesi AMOS uygulamları. Ankara: Detay Yayıncılık. 
Mol, M. J., \& Birkinshaw, J. (2009). The sources of management innovation: When firms introduce new management practices. Journal of Busines Research, 62, 1269-1280.

Moore, L., \& Craig, L. (2008). Intellectual capital in enterprise success: Strategy revisited. New Jersey: John Wiley \& Sons. O’Donnell, D. (2004). Theory and method on intellectual capital creation. Journal of Intellectual Capital, 5(2), $294-311$.

Oslo, K. (2005). Yenilik verilerinin toplanması ve yorumlanması için ilkeler (3. Baskı). Ankara: TÜBiTAK.

Önce, S. (1999). Muhasebe bakış açısı ile entelektüel sermaye. Eskişehir: Anadolu Üniversitesi İktisadi ve İdari Bilimler Fakültesi Yayınları, No:151.

Özdevecioğlu, M., \& Biçkes, M. D. (2012). Örgütsel öğrenme ve inovasyon ilşkisi: Büyük ölçekli işletmelerde bir araştırma. Erciyes Üniversitesi İktisadi ve İdari Bilimler Fakültesi Dergisi, (39), 19-45.

Pabuşcu, H., \& İmamoğlu, í. (2017). Yeniliğin belirleyicileri: Yatay kesit veri analizi. Gazi Üniversitesi İktisadi ve İdari Bilimler Fakültesi Dergisi, 19(1), 110-129.

Peçen, Ü., \& Kaya, N. (2013). Amerika Birleşik Devletleri firmalarında insan kaynakları yönetimi uygulamaları, organizasyonel iklim ve organizasyonel yenilikçilik düzeyi. Dogus University Journal, 14(1), 95-111.

Pena, I. (2002). Intellectual capital and business start-up success. Journal of Intellectual Capital, 2(2), 180-198.

Peng, T. J. A., Pike, S., \& Roos, G. (2007). Intellectual capital and performance indicators: Taiwanese healthcare sector. Journal of Intellectual Capital, 8(3), 538-556

Preacherr, J. K., \& Leonardelli, G. J. (2017). Calculation for the Sobel test an interactive Calculation tool for mediation tests. http://quantpsy.org/sobel/sobel.htm [Erişim Tarihi: 12 Temmuz 2017].

Ramirez, Y. J. P. (2010). Intellectual capital models in Spanish public sector. Journal of Intellectual Capital, 11(2), 248264.

Ruiz-Arroyo, M., Mar Fuentes-Fuentes, M., Bojica, A. M., \& Rodríguez-Ariza, L. (2012). Innovativeness and performance in women-owned small firms: The role of knowledge acquisition. Journal of Small Business \& Entrepreneurship, 25(3), 307-326.

Samuel, C. C. (2000). Modern management diversity, quality, ethics \& the global environment. London: Prentice Hall International Inc.

Santos-Rodrigues, H., Faria, J., Cranfield, D., \& Morais, C. (2013). Intellectual capital and ınnovation: A case study of a public healthcare organisation in Europe. Electronic Journal of Knowledge Management, 11(4), 361-372.

Seetharaman, A., Low, K. L. T., \& Saravanan, A. (2004). Comprative justification on iıntellectual capital. Journal of Intelectual Capital, 5(7), 522-539.

Sharabati, A., Javad, S. N., \& Bontis, N. (2010). Intellectual capital and business performance in the pharmaceutical sector of Jordan. Management Decision, 48(1), 105-131.

Stewart, T. A. (1997). Entelektüel sermaye: Kuruluşların yeni zenginliği. Çev.: Nurettin Elhüseyni, İstanbul: Mess Yayınları.

Subramaniam, M., \& Youndt, M. A. (2005). The influence of intellectual capital on the types of innovative capabilities. Academy of Management Journal, 48(3), 450-466.

Taş, S. (2017). İnovasyon, eğitim ve küresel innovasyon endeksi. Bilge Uluslararsı Sosyal Araştırmalar Dergisi, 1(1), 99123.

Toraman, C., Abdioğlu, H., \& İ̧̧güden, B. (2009). İşletmelerde inovasyon sürecinde entelektüel sermaye ve yönetim muhasebesi kapsamında değerlendirilmesi. Afyon Kocatepe Üniversitesi iiBF Dergisi, 11(1), 91-120.

Tuna, O., \& Arabelen, G. (2013), Deniz ulaştırma lojistiği. Denizicilik işletmeleri yönetimi, Cerit, G., Deveci, A. ve Esmer, S. (ed.), İstanbul: Beta Yayıncılık, 544-550.

Türkoğlu, N., \& Çizel, B. (2016), Konaklama işletmelerinde entelektüel sermayenin rekabet gücüne etkisi. Turizm Akademik Dergisi, 3(2), 37-53.

Williams, S. M. (2001). Is a company's intellectual capital performance and intellectual capital disclosure practices related? Evidence from publicly listed companies from the FTSE 10. 4th. World Congress on Intellectual Capital, 1-34.

Wu, Y. C. J., \& Chou, Y. H. (2007). A new look at logistics business performance: Intellectual capital perspective. The International Journal of Logistics Management, 18(1), 41-63.

Yang, C. C. (2012). Assessing the moderating effect of innovation capability on the relationship between logistics service capability and firm performance for ocean freight forwarders. International Journal of Logistics: Research and Applications, 15(1), 53-69. 
Yazıcıoğlu, Y., \& Erdoğan, S. (2004). SPSS uygulamalı bilimsel araştırma yöntemleri. Ankara: Detay Yayıncılık.

Yıldız, S. (2011). Entelektüel sermayenin işletme performansına etkisi: Bankacılık sektöründe bir araştırma. Anadolu Üniversitesi Sosyal Bilimler Dergisi, 11(3), 11-27.

Youndt, M. A., Subramaniam, M., \& Snell, S. A. (2004). Intellectual capital profiles: An examination of investments and returns. Journal of Management Studies, 41(2), 335-361.

Yorulmaz, M. (2017). Deniz ulaştırma lojistiği. İstanbul: Nobel Yayıncılık.

Zehir, C., \& Özşahin, M. (2006). Stratejik karar verme hızını etkileyen örgütsel, çevresel faktörler ve firma performansı ilişkisi: İmalat sektöründe bir saha çalışması. Gazi Üniversitesi İktisadi ve İdari Bilimler Fakültesi Dergisi, 9(1), 137157. 


\section{Ekler}

\section{EK 1. Anket Formu}

\section{İnsan Sermayesi}

1. Çalışanlarımız yeterli iş tecrübesine sahiptir.

2. Çalışanlarımızın iş performansı yüksektir.

3. Çalışanlarımızın eğitimlerine ve yeteneklerinin geliştirilmesine destek oluruz.

4. Nitelikli ve eğitimli çalışanlarımızın aniden işten ayrılması firmamızı etkiler.

5. Çalışanlarımızın firmaya bağıııkları yüksektir.

6. Firmamızda işe alınacak personelin mezun olduğu okul, tercih sebebidir.

7. Firmamızda performans değerlendirme sistemi vardır.

8. Çalışanlarımız ekipler halinde çalışma konusunda isteklidirler.

9. Çalışanlarımız sahip oldukları bilgiyi paylaşma konusunda isteklidirler.

10. Yöneticiler çalışanları firma amaçlarına doğru yönlendirmekte başarıııdır.

11. Yöneticilerin gerekli hallerde risk alabilecek potansiyele sahip olmaları sağlanmaktadır.

\section{Yapısal Sermaye}

12. Firmamızda iş süreçlerimiz tanımlanmıştır.

13. Firmamızın iş yapma biçimi tüm çalışanlarımızca benimsenmektedir.

14. Firma çalışanları tarafından benimsenen ve paylaşılan misyon, vizyon ve kurumsal değerlerimiz vardır.

15. Firmamızda uyumlu bir çalışma ortamı vardır.

16. Firmamızda sürekli olarak gelişimi sağlayan bir örgüt kültürü vardır.

17. Firmamızda katılımcı bir yönetim anlayışı vardır.

18. Bilgisayar, veri tabanı, internet, iç ağ (intranet) ve yazılımlar gibi bilişim teknolojileri, sektör intiyaçları doğrultusunda geliştirilmekte ve güncellenmektedir.

19. Emniyetli yönetim sistemimiz çalışanlarımızın performansını artırmaktadır.

20. Firmamız faaliyetlerinde kendisini topluma ve çalışanlarına karşı sorumlu hissetmektedir.

\section{ìlişkisel Sermaye}

21. Hizmetlerimiz hakkında müşteriler bilgilendirilir.

22. Müşterilerimizle etkin bir iletişimimiz vardır.

23. Tedarikçilerimizle etkin bir iletişimimiz vardır.

24. Müşterilerimizin istek ve ihtiyaçlarını karşılamak için onlarla sürekli iş birliği yaparız.

25. Müşterilerimizle ilişkilerimiz uzun dönemlidir.

26. Tedarikçilerimizle ilişkilerimiz uzun dönemlidir.

27. Müşteri profili firma çalışanlarınca bilinmektedir.

28. Müşterilerimiz çoğunluğu firmamızın hizmetlerinden memnundur.

29. Firmamızın imajı sürekli artmaktadır.

Yenilikçilik:

30. Firmamızda yenilikçi düşüncelere değer verilir ve cesaretlendirilir.

31. Firma amaçlarına ulaşmak için en iyi yolları bulmaya çalışırız.

32. Operasyonel sistemlerimizi geliştirmek için çaba sarf ederiz.

33. Teknolojik yeniliklere kolay uyum sağlarız.

34. Geliştirilen iş süreçleri firmamıza önemli katkılar sağlamıştır.

\section{Örgüt Performansı:}

35. Hizmet kalitemiz rakiplerimize göre daha iyidir.

36. Müşterilerimizin firmamıza bağlılıkları rakiplerimizden yüksektir.

37. Karlılık oranımız rakiplerimize kıyasla daha yüksektir.

38. Yatırımlarımızın getirisi rakiplerimize kıyasla daha yüksektir.

39. Pazar payımız rakiplerimize kıyasla yüksektir.

40. Taşıma maliyetlerimiz rakiplerimizden daha düşüktür. 